\title{
Modeling and Simulation of Deformation Mechanism of Soft Rock Roadway considering the Mine Water
}

\author{
Yanlong Chen $\left(\mathbb{D},{ }^{1}\right.$ Qiang Li, ${ }^{2}$ Hai Pu, ${ }^{1,3}$ Peng Wu $\mathbb{D},{ }^{1}$ Liang Chen, ${ }^{1}$ Deyu Qian, \\ Xuyang Shi $\mathbb{D}^{4}{ }^{4}$ Kai Zhang, ${ }^{1}$ and Xianbiao Mao $^{2}$ \\ ${ }^{1}$ State Key Laboratory for Geomechanics and Deep Underground Engineering, China University of Mining and Technology, \\ Xuzhou 221116, China \\ ${ }^{2}$ School of Mechanics and Civil Engineering, China University of Mining and Technology, Xuzhou 221116, China \\ ${ }^{3}$ College of Mining Engineering and Geology, Xinjiang Institute of Engineering, Urumqi 830091, China \\ ${ }^{4}$ School of Mines, China University of Mining and Technology, Xuzhou 221116, China \\ Correspondence should be addressed to Yanlong Chen; chenyanlong@cumt.edu.cn and Peng Wu; pengw@cumt.edu.cn
}

Received 25 May 2020; Revised 23 June 2020; Accepted 9 November 2020; Published 21 November 2020

Academic Editor: Fabien Magri

Copyright (C) 2020 Yanlong Chen et al. This is an open access article distributed under the Creative Commons Attribution License, which permits unrestricted use, distribution, and reproduction in any medium, provided the original work is properly cited.

\begin{abstract}
The existence of coal mine water has an important influence on the instability of soft rock roadway in mining engineering. Considering the effect of mine water, a case study on the fracture mechanism and control technology of soft rock roadway was performed in this paper. The results showed that with the increase of moisture content, the uniaxial compressive strength of mudstone nonlinearly decreased, while the tensile strength, Young's modulus, cohesion, and friction angle tended to a linear decrease approximately. Meanwhile, with the increase of the weakening coefficient, the axial force of the anchorage body increased gradually, while the maximum shear stress decreased gradually. With the increase of moisture content, the failure zone was further propagated into the deep surrounding rock, resulting in a larger stress relaxation around the roadway, especially in the roof and floor. Finally, the supporting technology of the roadway was proposed, and then its support principle, design process, and parameters were also analyzed in detail. The field monitoring data showed that the support technology can control the surrounding rock deformation effectively and maintain the long-term stability of the roadway.
\end{abstract}

\section{Introduction}

Coal resources play an important role in the energy structure, accounting for more than $70 \%$ of the total resources in China. With the increasing intensity of coal mining and the exhaustion of shallow coal resources, the coal mining depth gradually increases at a speed of $10 \mathrm{~m}$ to $25 \mathrm{~m}$ per year [1]. Under the influence of high temperature, hyperosmosis, high in situ stress, and dynamic pressure disturbance, internal fractures of the rock masses develop and expand, eventually leading to the deformation of the roadway $[2,3]$. Therefore, the failure mechanism of deep roadway is more complex than that of shallow roadway, especially in the soft rock. Engineering data have indicated that deep soft rock roadway accounts for about $28 \%-30 \%$ of the total roadways, nevertheless, the repair rates are as high as $70 \%[4,5]$. Besides, the maintenance cost for the overall safety of the roadway is extremely expensive. Therefore, research on soft surrounding rock roadway is one of the pressing issues at home and abroad.

Grasping the instability mechanism of soft rock roadway is essential for the establishment of a support scheme in underground engineering. Theoretical analysis, numerical simulation, and engineering practice on the instability mechanism of soft rock roadway have been studied in the previous studies. Xue et al. [6] analyzed the theory of stacked arch bearing arch strength and applied this theory into the design of roadway support. Wang et al. [7] claimed that the unreasonable support scheme cannot effectively bear the 
deformation and loosening pressure, resulting in the large deformation of deep roadway. Li et al. [8] applied $\mathrm{PFC}^{2 \mathrm{D}}$ to simulate the rock breakage modes under the confining pressure in deep mining. Zhang et al. [9] used FLAC ${ }^{3 \mathrm{D}}$ to study the instability of gypsum mining goaf under the influence of typical faults. Zhu et al. [10] explored the temporal and spatial evolution of stress at the floor of the coal seam by FLAC ${ }^{3 \mathrm{D}}$. Considering that the high horizontal in situ stress is the major cause of roadway instability, Mark et al. [11] and Shen [12] simulated the failure mechanism of soft rock roadway by UDEC. Tang and Tang [13] simulated the floor heave processes of a swelling rock tunnel under the high humidity through simulation with RFPA. González-Nicieza et al. [14] investigated the influence of the depth and cross-section of the tunnel on the radial displacement by the convergenceconfinement method (CCM). In addition, the low compressive and shear strength and the development of joints and cracks have important influences on the large deformation of the soft rock roadway $[15,16]$. These studies have shown that the failure mechanism of soft rock roadway is not only related to the geological condition, in situ stress state, and rock mass parameters but also closely related to roadway size and section shape. In other words, the failure mechanism of soft rock roadway is complex, and some special supporting methods are required under different characteristics of the soft roadway $[17,18]$.

Recently, studies on the large deformation of soft rock roadway have been carried out, and some achievements have been obtained [19-21]. Based on the previous research and application, basic control techniques of soft rock roadway are summarized from the following four aspects: (1) the active support method is mainly used to improve the shear stiffness and tensile strength of the shallow surrounding rock and resist the harmful deformation of the roadway, such as bolt and cable [2, 22-24]. (2) The flexible passive support structure can resist the residual deformation of surrounding rock effectively, such as traditional U-steel, concrete-filled steel tubular, building arch, and steel tube confined concrete supports [25-28]. (3) Grouting reinforcement can improve the bearing capacity of the shallow surrounding rock [16, 29-31]. (4) A certain thickness of the compressive layer is reserved between the roadway surface and the passive support structure to effectively release the deformation energy of surrounding rock $[4,32-34]$. Due to the complexity of geological conditions of soft rock roadway, the large and long-duration deformation in soft rock tunnel engineering is difficult to be controlled by a single support method. In the engineering practice, the combination support scheme has been proved to be an effective solution for such a support problem.

Due to the unique geological conditions, control technologies of soft rock roadway may not be applicable in different underground engineering. In this paper, the failure mechanism and control technology were studied to effectively control the large deformation of water-dripping soft rock roadway. Firstly, evolution laws of mudstone parameters with the moisture content were discussed comprehensively by the laboratory test. Secondly, the influence of mine water on the stress state of the anchorage body was researched by introducing a weakening coefficient. Thirdly, with the change of moisture content, the deformation and plastic zone development process of surrounding rock were analyzed by the numerical simulation with FLAC ${ }^{3 \mathrm{D}}$. Finally, the new waterproof supporting method was proposed to support the roadway.

\section{Engineering Properties of the Soft Roadway}

2.1. Engineering Setting. As shown in Figure 1(a), No. 4 coal mine of Saier Group is located in the northwest of the Xinjiang Autonomous Region, China. The B1002 haulage roadway of No.4 coal mine is excavated in the 10\# coal seam, with a total length of $1200 \mathrm{~m}$ and an average burial depth of $320.66 \mathrm{~m}$. In addition, both the belt and rail transportation functions are used in the haulage roadway, so there is a large section for the haulage roadway. The detailed arrangement of the haulage roadway is shown in Figure 1(b).

The cross-section of the haulage roadway is rectangular and excavated in the 10\# coal seam with the width and height of $5000 \mathrm{~mm}$ and $3600 \mathrm{~mm}$. The surrounding rock of the haulage roadway is mainly composed of mudstone and pack sand. The mudstone is mainly distributed on the surface of the roadway surrounding rock, with the soft property and poor cementing effect. The average distance from the roadway to the pack sand in roof and pack sand in floor is $5.0 \mathrm{~m}$ and $3.2 \mathrm{~m}$, and pore water is rich in pore water. Figure 2 shows the lithological column of the roadway. In addition, bolt-mesh-cable combined support is mainly adopted in the primary support method of the haulage roadway. Two kinds of bolt and cable are used: (1) $2000 \mathrm{~mm}$ with the pretightening force of $30 \mathrm{kN}$; and (2) $5400 \mathrm{~mm}$ with the pretightening force of $60 \mathrm{kN}$. The crosssection and support patterns are shown in Figure 3.

2.2. Mineral Composition Analysis. The average mineral composition of mudstone was obtained by an X-ray diffraction spectrum, as shown in Figure 4. It can be seen that rock specimens include abundant minerals such as quartz, kaolinite, smectite, illite, and less feldspar, calcite. The clay mineral composition is up to $74.5 \%$, indicating that mudstone specimens belong to the swelling soft rock. When it encounters mine water, great expansive force will be generated by the mudstone, resulting in accelerated damage to the roadway stability.

2.3. Deformation Characteristics of Soft Rock Roadway. After roadway excavation, based on the investigation and monitoring data of the haulage roadway in two months, the deformation and support structure failure characteristic of the roadway are summarized as follows:

(1) Large deformation and high deformation speed. The large deformation of surrounding rock appeared after two months of the roadway excavation. The average roof subsidence, floor heaves, and side walls convergence were $450 \mathrm{~mm}, 420 \mathrm{~mm}$, and $930 \mathrm{~mm}$, respectively. In some areas, the accumulative deformation was as large as 1.2-1.4 times compared with the above results, and the maximum side walls convergence reached $1400 \mathrm{~mm}$ and the section shrinkage rate reached $65 \%$. In addition, due to the influence of 


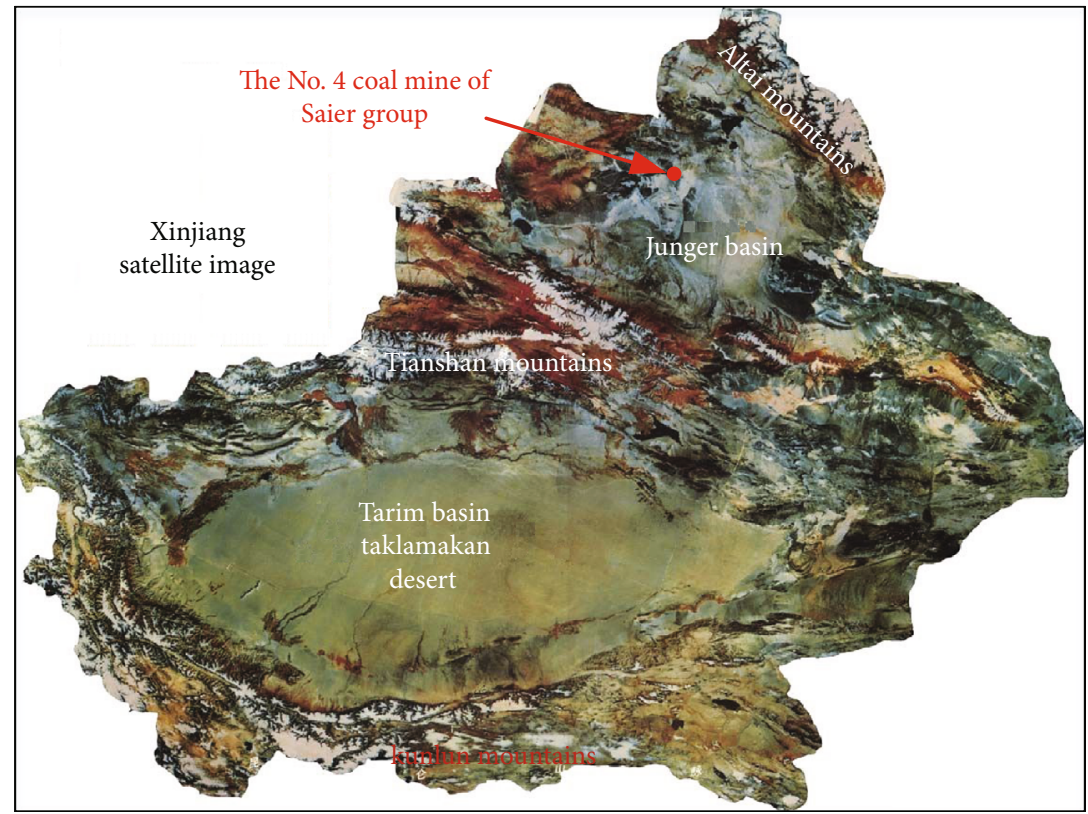

(a)

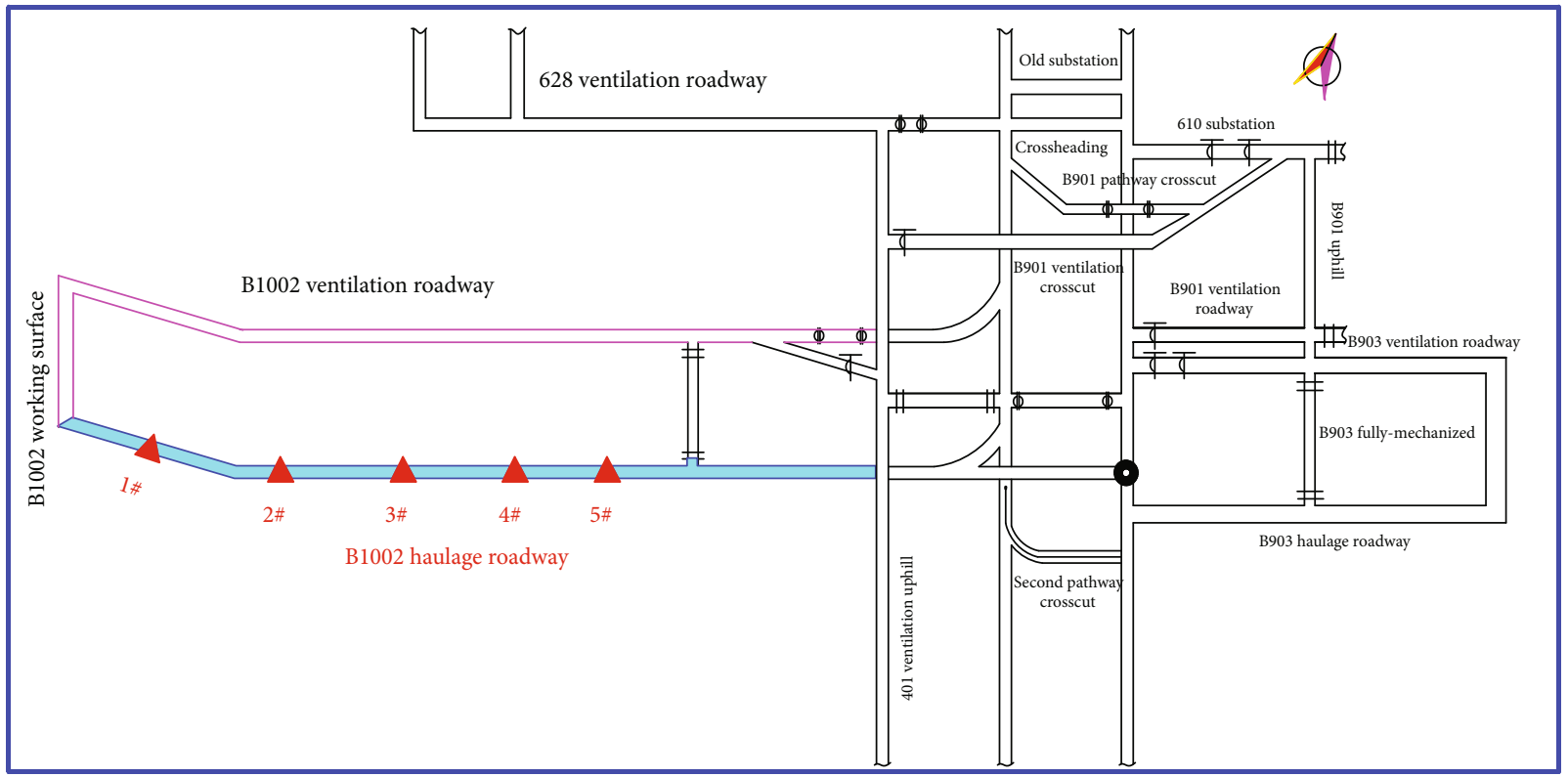

(b)

Figure 1: The detailed arrangement of the haulage roadway. (a) Location of the No.4 coal mine of Saier Group. (b) B1002 haulage roadway layout in No.4 coal mine.

packstone pore water on the mudstone, the strength of the rock mass decreased gradually with time, and the deformation of the surrounding rock lasted for a long period, resulting in extremely poor stability. The monitoring data indicated that the general deformation speed of surrounding rock was $5 \mathrm{~mm} / \mathrm{d}-8 \mathrm{~mm} / \mathrm{d}$, while some were up to $12 \mathrm{~mm} / \mathrm{d}$

(2) Support structure failure. Due to unreasonable support methods, the phenomena of roof collapse, mesh tearing failure, and corrosion failure of bolt, as well as weakening of surrounding rock, were easily occurred under the effect of the high in situ stress and pack sand pore water. With the influence of mine water, corrosion failure of support structure was more serious (Figure 5(a)), and the bolt (cable) support strength decreased significantly. Next, the extrusion and stagger displacement appeared in the roof, resulting in the roof subsidence (Figure 5(b)). The two sides moved towards the free surface, and then metal mesh and trapezoidal beam were subject to the tensile and shear failure (Figure 5(c)). Finally, the roof collapse accident happened along the weak 


\begin{tabular}{|c|c|c|c|c|}
\hline Column & No & Lithology & Thickness (m) & Lithological characters \\
\hline \multirow[t]{2}{*}{$\begin{array}{l}----- \\
----- \\
----- \\
----- \\
\end{array}$} & 1 & Siltstone & 6.0 & $\begin{array}{l}\text { Gray green, horizontal } \\
\text { bedding, thin sandstone } \\
\text { interbed. }\end{array}$ \\
\hline & 2 & Mudstone & 3.7 & $\begin{array}{l}\text { Grey, gently slope bedding, } \\
\text { containing plants fossils, } \\
\text { broken. }\end{array}$ \\
\hline \multirow{4}{*}{ 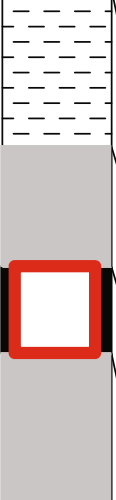 } & 3 & 9\# coal mine & 1.2 & $\begin{array}{l}\text { Anthracite coal, banded } \\
\text { structure, fractured }\end{array}$ \\
\hline & 4 & Packsand & 6.5 & $\begin{array}{l}\text { Gray, main containing quartz } \\
\text { and felpar, good integrity. }\end{array}$ \\
\hline & 5 & Mudstone & 5.0 & $\begin{array}{l}\text { Gray, gently slope bedding, } \\
\text { containing plants fossils, } \\
\text { broken. }\end{array}$ \\
\hline & 6 & 10\# coal mine & 3.6 & $\begin{array}{l}\text { Anthracite coal, banded } \\
\text { structure, fractured }\end{array}$ \\
\hline \multirow[t]{3}{*}{$\begin{array}{l}---- \\
----- \\
---- \\
\end{array}$} & 7 & Mudstone & 6.4 & $\begin{array}{l}\text { Gray, gently slope bedding, } \\
\text { containing plants fossils, } \\
\text { broken. }\end{array}$ \\
\hline & 8 & Sandy mudstone & 3.2 & $\begin{array}{c}\text { Black gray, gently slope } \\
\text { bedding, containing plants } \\
\text { fossils, moderate weathering. }\end{array}$ \\
\hline & 9 & Packsand & 10.4 & $\begin{array}{l}\text { Gray, main containing quartz } \\
\text { and felpar, good integrity. }\end{array}$ \\
\hline
\end{tabular}

FIgURE 2: Strata histogram and lithological characters.

interface with the serious caved side walls (Figure 5(d)). The surrounding rock presented large deformation characteristic

(3) The roadway deformation presented the timedependent characteristic. After being excavated, the surrounding rock of the roadway always kept a high deformation ratio over time. Deformation duration lasted for about 4 months

2.4. The Influence of Moisture Content on Rock Mass. Based on the field investigation, the mine water was the main cause of the large deformation of surrounding rock [35]. Therefore, it was necessary to research the influence of mine water on the mudstone parameters by laboratory tests to obtain the instability mechanism of haulage roadway. In this test, moisture contents were adjusted to a predetermined value by a spraying method. The tensile $\left(\sigma_{t}\right)$ and compressive strengths $\left(\sigma_{c}\right)$ evolution law with the moisture content $(\rho)$ were shown in Figure 6. It is seen that the compressive strength decreases nonlinearly with the increase of moisture content. As shown in Table $1, \rho$ increases from $1.43 \%$ to $3.33 \%-5.56 \%$, and $\sigma_{c}$ decreases by $13.45 \%-68.42 \%$, respectively. In addition, the relationship between tensile strength and moisture content is linear approximately. For instance, $\rho$ increases from $1.43 \%$ to $3.33 \%$ or from $3.33 \%$ to $5.56 \%$, and $\rho$ decreases by $57.14 \%$ and $83.33 \%$, respectively. Figure 7 shows the influences of moisture content on the Young's modulus $(E)$, cohesion $(c)$, and friction angle $(\varphi)$ of mudstone. It should be noted that the Young's modulus can be determined by taking the slope of $40 \%-60 \%$ of the stress-strain curve. It is seen that parameters $(E, c$, and $\varphi)$ decrease linearly with the increase of moisture content. For example, $\rho$ increases from $2.42 \%$ to $4.54 \%$, the Young's modulus decreases by $59.62 \%$, cohesion decreases by $37.5 \%$, and friction angle decreases by $12 \%$. Therefore, the mine water has an important effect on the mudstone parameter attenuation, and the influence of mine water should be considered in the instability mechanism and support method optimization of surrounding rock. The relationships between moisture content and mechanical parameters of mudstone are shown in the following equation.

$$
\left\{\begin{array}{l}
\sigma_{c}=-0.5199 \rho^{2}+0.7101 \rho+18.1225\left(R^{2}=0.9113\right) \\
\sigma_{t}=-0.3289 \rho+1.7750\left(R^{2}=0.9798\right) \\
E=-0.2948 \rho+1.8191\left(R^{2}=0.9401\right) \\
c=-0.5247 \rho+3.9443\left(R^{2}=0.9282\right) \\
\varphi=-1.2863 \rho+27.8713\left(R^{2}=0.9856\right)
\end{array}\right.
$$




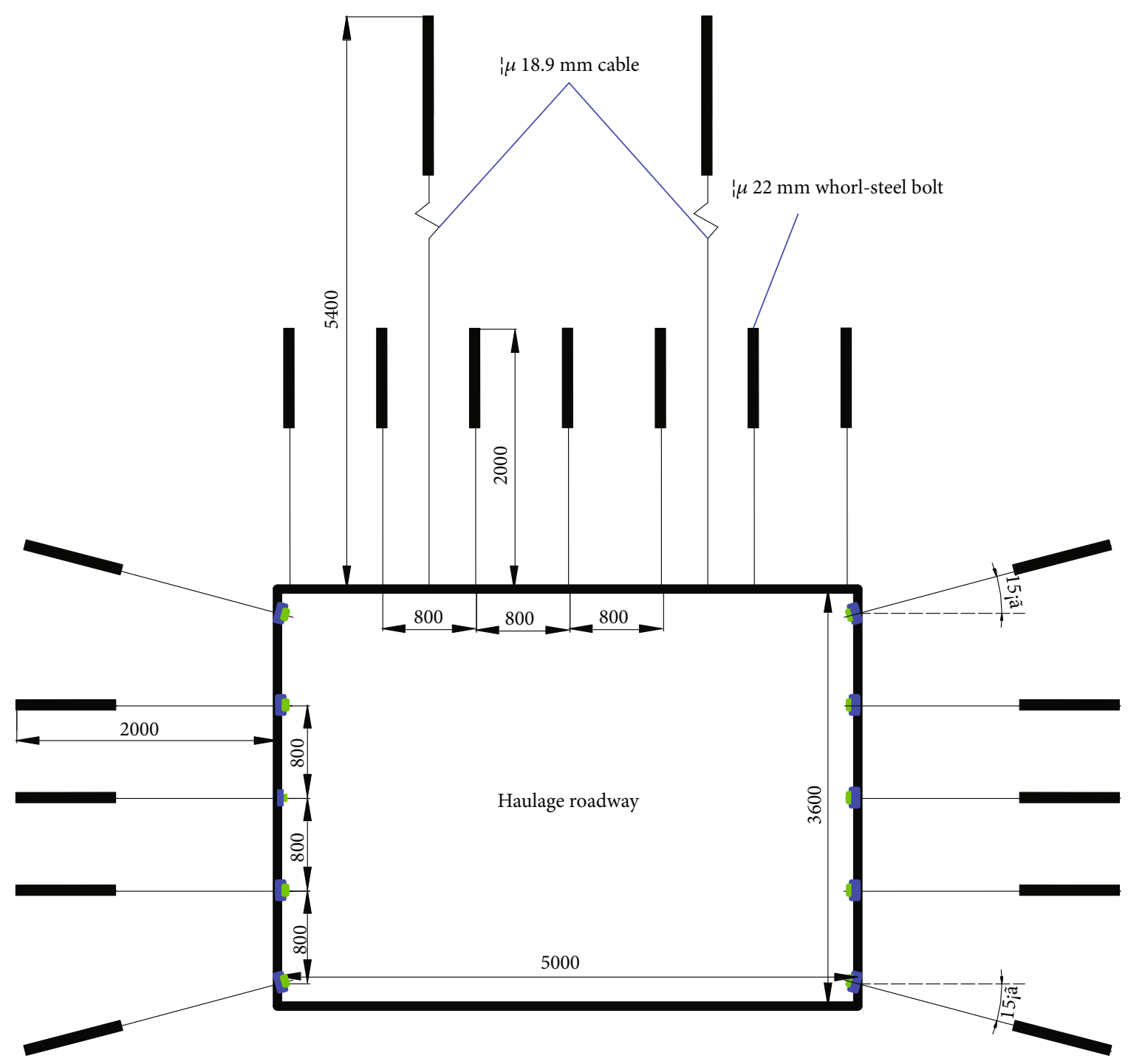

Figure 3: Primary support of the haulage roadway.

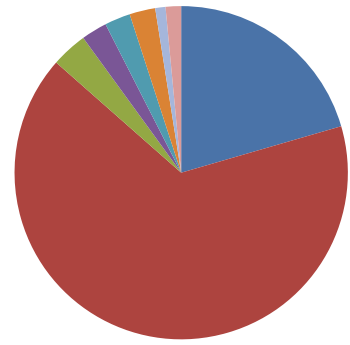

Quartz

- Kaolinite

- Smectite

- Illite

- Illite-smectite mixed layer

- Feldspar

- Calcite

Others

FIgURE 4: The mineral composition of mudstone located on the surrounding rock surface of the roadway.

\section{The Support Mechanical Characteristics of a Bolt under Water-Dripping Condition}

Based on the results of laboratory tests in Section 2.4, the existence of mine water reduces the rock masses mechanical properties effectively and weakens the bearing capacity of surrounding rock. Since bolt support can effectively change the stress state of surrounding rock and enhance the strength and stability of the anchorage rock mass, it has been widely used in different kinds of soft rock engineering in China $[2,31]$. However, mine water not only corrodes the bolt body but also weakens the anchorage strength at the grout-bolt or grout-rock mass interface. As a result, the bolt support effect is greatly reduced, and the instability risk of surrounding rock is enhanced. Therefore, it was necessary to research the stress evolution process of the rock bolt under different water-dripping conditions.

3.1. Mechanical Model Establishment. The mechanical calculation model of the grout bolt drilled into rock mass is shown 


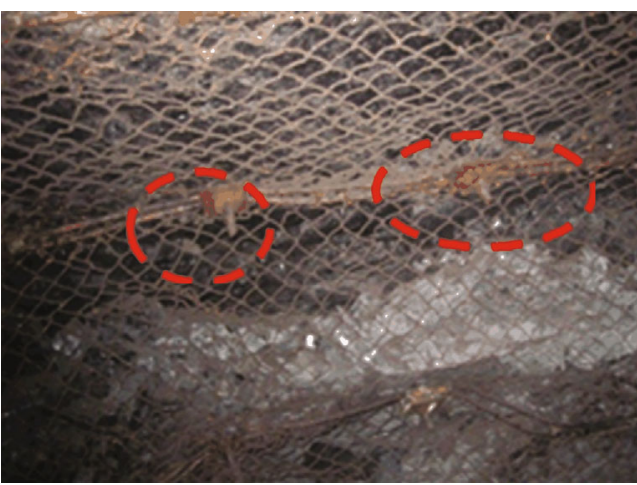

(a)

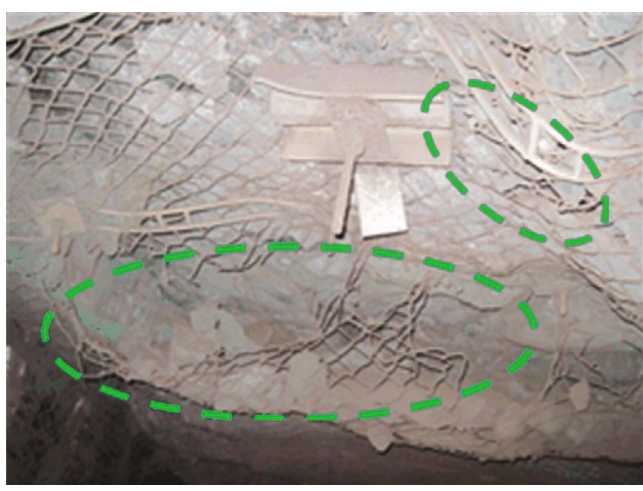

(c)

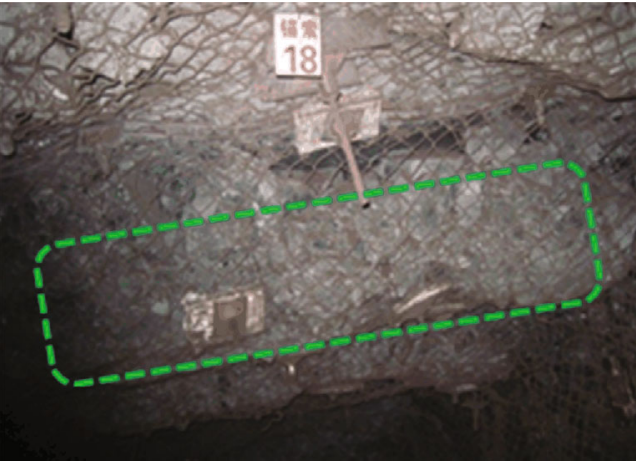

(b)

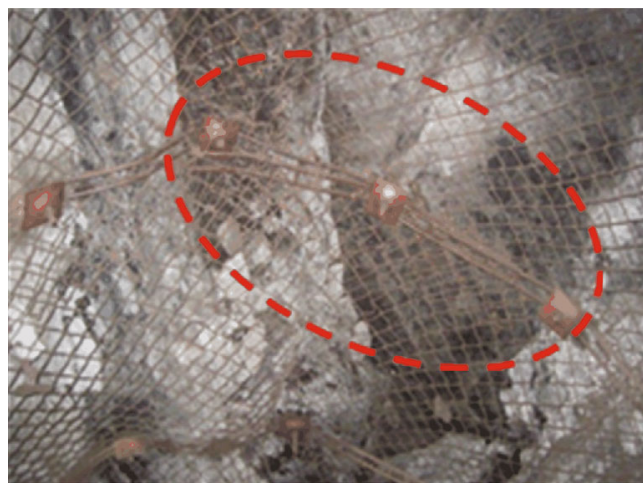

(d)

FIGURE 5: The deformation and support structure failure characteristic of surrounding rock. (a) Water-dripping corrosion of supporting structure; (b) roof subsidence; (c) mesh tearing and trapezoidal beam failure; (d) roof collapse.

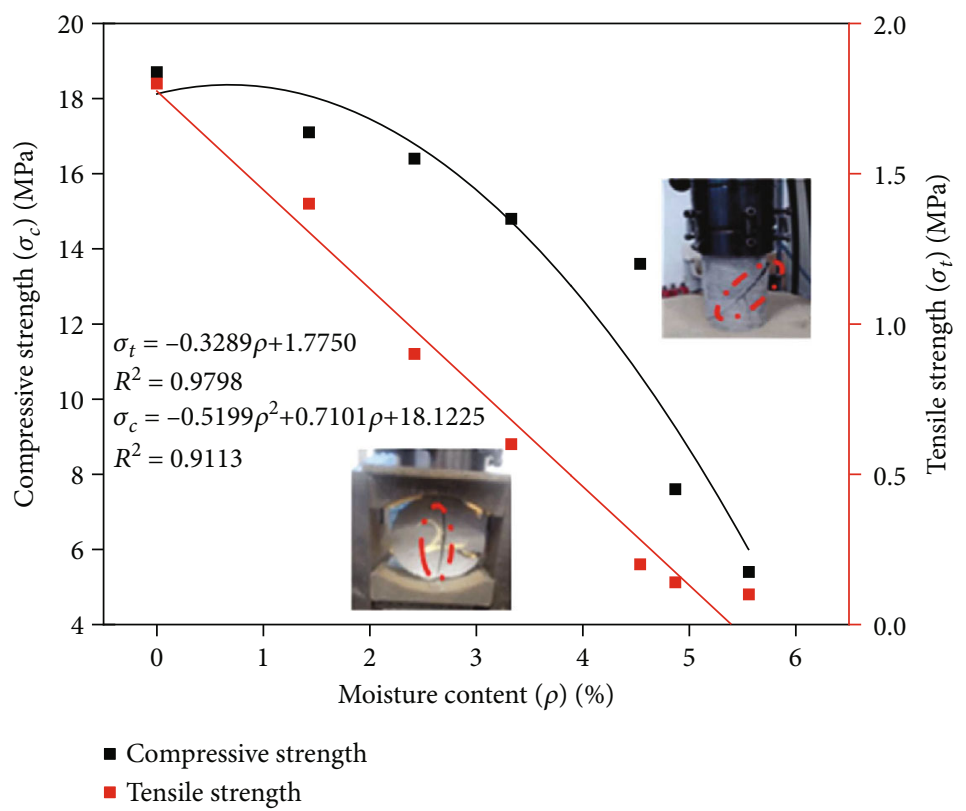

FIgURE 6: Influence of moisture content on the compressive and tensile strength of mudstone.

in Figure 8. The outer radius of the bolt and grout is represented as $r_{a}$ and $r_{i}$, respectively. The total bolt length and anchorage length are $L$ and $L_{z}$, respectively. $F$ is the initial pretightening force applied to the rock bolt, and $\tau(z)$ is the shear stress along the anchorage failure interface. It should be noted that the possible failure interface may be located at (1) the grout-bolt interface, (2) grout-rock mass interface, and (3) internal grout, as shown in Figure 8. Due to the 
TABLE 1: Mudstone parameters under different moisture contents.

\begin{tabular}{|c|c|c|c|c|c|c|c|}
\hline $\begin{array}{l}\text { Moisture } \\
\text { content (\%) }\end{array}$ & $\begin{array}{c}\text { Compressive } \\
\text { strength }(\mathrm{MPa})\end{array}$ & $\begin{array}{c}\text { Tensile strength } \\
(\mathrm{MPa})\end{array}$ & $\begin{array}{l}\text { Bulk modulus } \\
(\mathrm{GPa})\end{array}$ & $\begin{array}{l}\text { Shear modulus } \\
(\mathrm{GPa})\end{array}$ & $\begin{array}{c}\text { Young's modulus } \\
\text { (GPa) }\end{array}$ & $\begin{array}{c}\text { Cohesion } \\
(\mathrm{MPa})\end{array}$ & $\begin{array}{l}\text { Friction } \\
\text { angle }\left(^{\circ}\right)\end{array}$ \\
\hline 0.00 & 18.7 & 1.8 & 1.20 & 0.72 & 1.80 & 4.3 & 28 \\
\hline 1.43 & 17.1 & 1.4 & 1.07 & 0.64 & 1.60 & 3.1 & 26 \\
\hline 2.42 & 16.4 & 0.9 & 0.69 & 0.42 & 1.04 & 2.4 & 25 \\
\hline 3.33 & 14.8 & 0.6 & 0.42 & 0.25 & 0.63 & 1.9 & 23 \\
\hline 4.54 & 13.6 & 0.2 & 0.28 & 0.17 & 0.42 & 1.5 & 22 \\
\hline 5.56 & 5.4 & 0.1 & 0.22 & 0.13 & 0.33 & 1.4 & 21 \\
\hline
\end{tabular}

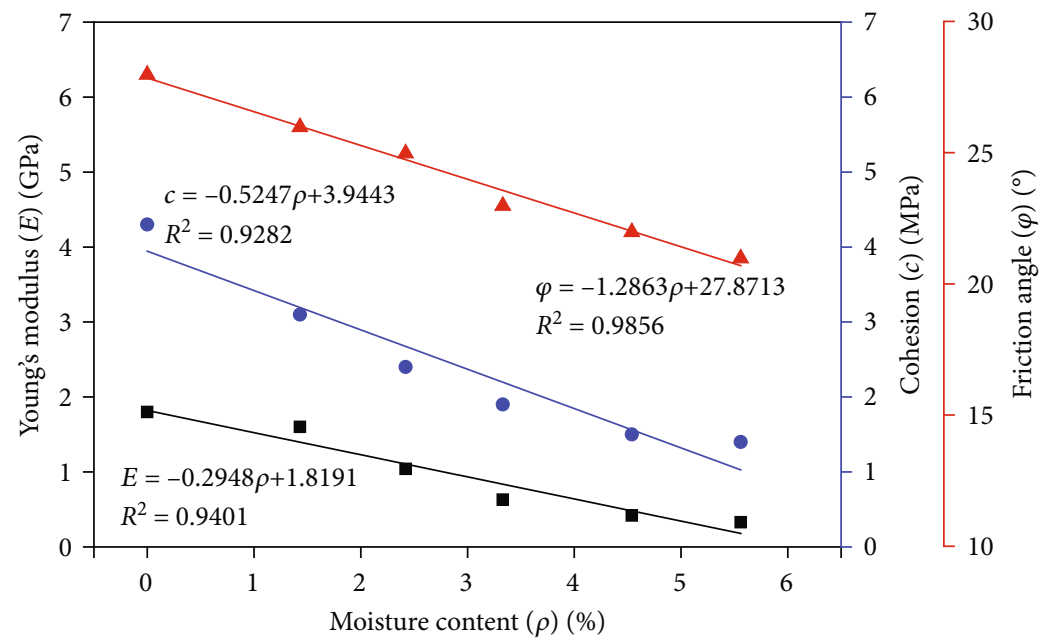

- Young's modulus

- Cohesion

$\Delta$ Friction angle

Figure 7: Influence of moisture content on the parameters $(E, c$, and $\varphi)$ of mudstone.

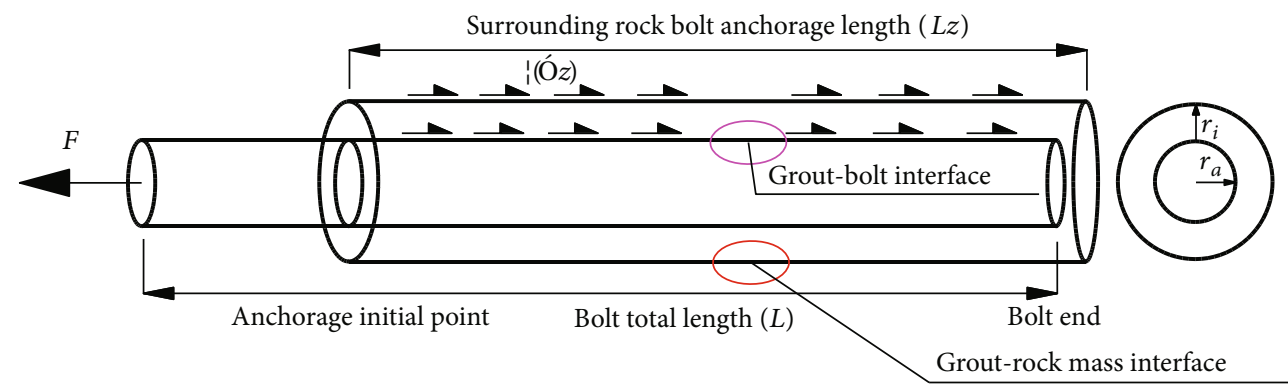

FIGURE 8: Mechanical calculation model of the mortar bolt drilled into rock mass.

relatively high strength of grout, grout-bolt interface and grout-rock mass interface are considered as the possible decoupling places. Therefore, the decoupling radius is written as follows:

$r_{j}=\left\{\begin{array}{l}r_{a} \text { Failure location at the grout-bolt interface, } \\ r_{i} \text { Failure location at the grout-rock mass interface. }\end{array}\right.$
According to the elastic theory, the relationship between the shear stress and shear displacement can be expressed as the following equation [2].

$$
\tau(z)=k_{j} u(z)
$$

where $k_{j}$ represents interface shear stiffness without considering the effect of mine water; the subscripts " $j$ " represents " $a$ " for the grout-bolt interface and " $i$ " for the grout-rock 


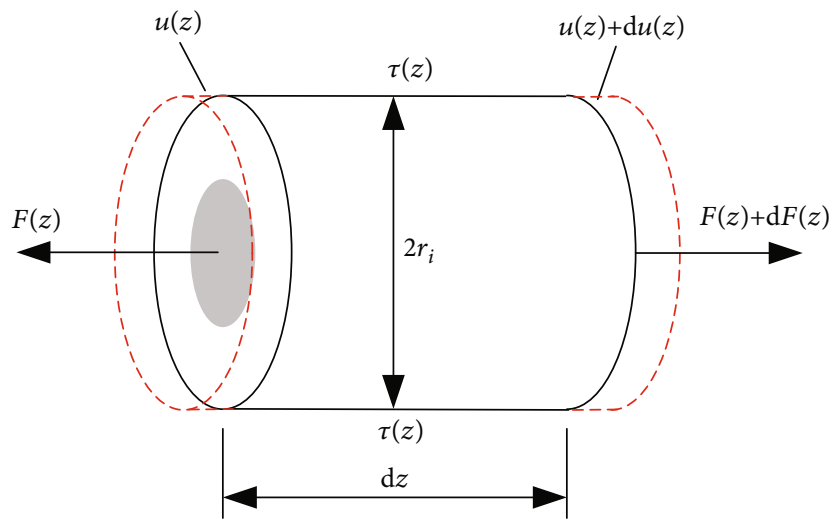

FIgURE 9: Microunit stress analysis of the anchoring body.

TABLE 2: The geometric and mechanical parameters of grout-bolt and bolt.

\begin{tabular}{lcccccccc}
\hline \multicolumn{3}{l}{ Bolt parameters } & \multicolumn{4}{c}{ Grout } \\
\multicolumn{1}{l}{$\begin{array}{c}L \\
(\mathrm{~m})\end{array}$} & $L_{z}$ & $r_{a}$ & $E_{b}$ & $r_{i}$ & $E_{g}$ & $k_{a}$ & $k_{i}$ & $F$ \\
& $(\mathrm{~mm})$ & $(\mathrm{GPa})$ & $(\mathrm{mm})$ & $(\mathrm{GPa})$ & $(\mathrm{GPa})$ & $(\mathrm{GPa})$ & $(\mathrm{kN})$ \\
\hline 2.0 & 1.2 & 10 & 200 & 13 & 120 & 75 & 35 & 60 \\
\hline
\end{tabular}

mass interface, respectively. $u(z)$ is the relative displacement between the anchorage body and surrounding rock.

When the rock encounters the mine water, mechanical properties of rock are weakened at the interface. Hence, the weakening coefficient $(\lambda)$ is introduced to define the weakening degree of rock mass, as shown in the following equation.

$$
\lambda=\frac{k_{j}-k_{m}}{k_{j}},
$$

where $\lambda$ is called weakening coefficient and satisfies $0 \leq \lambda<1$. If $\lambda=0$, then the rock mass is not affected by the water dripping. If $\lambda \rightarrow 1$, then rock mass is seriously affected by water and the bolt loses its anchoring action. $k_{m}$ is the weakened interface shear stiffness by water. Then, the shear stress at the interface is obtained by substituting Equation (4) into Equation (3).

$$
\tau(z)=(1-\lambda) k_{j} u(z)
$$

Deformation coordination conditions should be satisfied by the anchorage body and surrounding rock. Figure 9 shows the microunit stress analysis model of the anchoring body. Hence, according to the Hook's law, the relationship between the relative displacements of the anchoring body $u(z)$ and the pretightening force of the bolt $F(z)$ is expressed by the following equation [31].

$$
\frac{F(z)}{\pi r_{j}^{2}}=\frac{\mathrm{d} u(z)}{\mathrm{d} z} E_{j}
$$

where $E_{j}$ is the equivalent elastic modulus of the anchoring body; $E_{j}=E_{b}$ is valid for the failure location at the grout- bolt interface or $E_{j}=\left[E_{g}\left(r_{i}^{2}-r_{a}^{2}\right)+E_{b} r_{a}^{2}\right] / r_{i}^{2}$ for the failure location at the grout-rock mass interface. $E_{g}$ and $E_{b}$ is the elastic modulus of the grout and bolt, respectively.

Based on the stress equilibrium condition of the microelement body, the relationship between shear stress of the anchorage body and pretightening force along direction is expressed by the following equation.

$$
\frac{\mathrm{d} F(z)}{\mathrm{d} z}=2 \pi r_{j} \tau(z)
$$

By integrating the Equations (5) and (7) into Equation (6), Equation (8) is obtained as follows:

$$
\frac{\mathrm{d}^{2} u(z)}{\mathrm{d} z^{2}}-\frac{2(1-\lambda) k_{j}}{r_{j} E_{j}} u(z)=0 .
$$

According to the solution of Equation (8), the boundary conditions $F(L)=0$ and $F\left(L-L_{z}\right)=F$, the axial force and shear stress of the anchorage body along the $z$ direction under the effect of the water dripping are obtained as follows:

$$
\left\{\begin{array}{l}
F(z)=\frac{F}{1-e^{2 L_{z} \sqrt{2(1-\lambda) k_{j} / r_{j} E_{j}}}}\left[e^{\sqrt{\frac{2(1-\lambda) k_{j}}{\tau_{j} k_{j}}}\left(-L+L_{z}+z\right)}-e^{\sqrt{\frac{2(1-\lambda) k_{j}}{\left(-k_{j}\right.}}\left(L+L_{z}-z\right)}\right], \\
\tau(z)=\frac{1}{\pi} \sqrt{\frac{(1-\lambda) k_{j}}{2 r_{j}^{3} E_{j}}} F(z) .
\end{array}\right.
$$

3.2. Parameters Analysis. To research the influence of the weakening coefficient on the axial force and shear stress of anchorage body under different failure interfaces, different weakening coefficients $(0,0.2,0.4,0.6$, and 0.8$)$ were selected. The geometric and mechanical parameters of grout-bolt and bolt are shown in Table 2 .

Figure 10 presents the influence of different weakening coefficients on the axial force and shear stress of the anchorage body. It indicates that the weakening coefficient has an extremely important effect on the axial force and shear stress distribution of the anchorage body whether the failure location at the grout-bolt interface or the grout-rock mass interface. With the increase of the weakening coefficient, the axial force of the anchorage body increases gradually from the anchorage initial point to the end of the bolt under the same pretightening force, while the maximum shear stress decreases gradually. In addition, when the weakening coefficient is small, the shear stress is mainly concentrated near the anchorage initial point. With the increase of the weakening coefficient, the distribution of shear stress transforms from the anchorage initial point to the whole length of the bolt gradually. The above analysis shows that the mine water not only affects the anchoring action of the bolt to the surrounding rock but also causes the redistribution of bolt axial stress. 


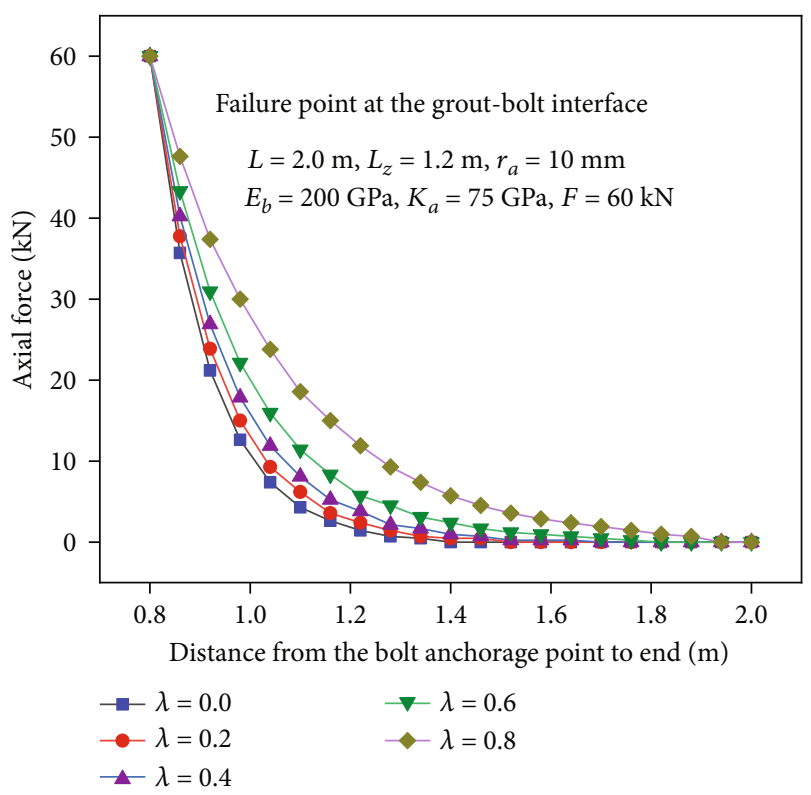

(a)

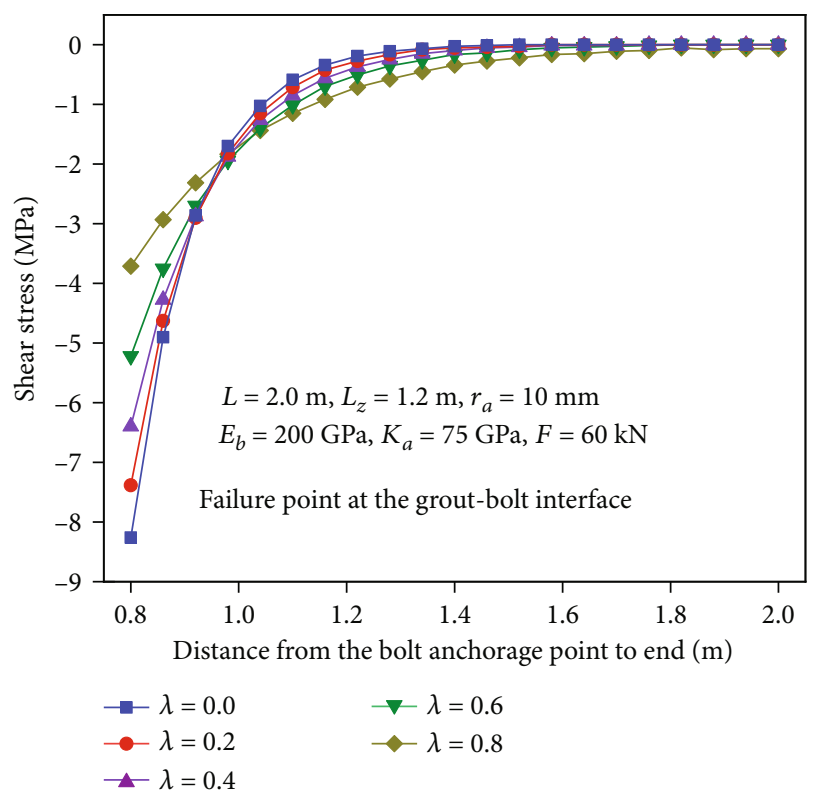

(c)

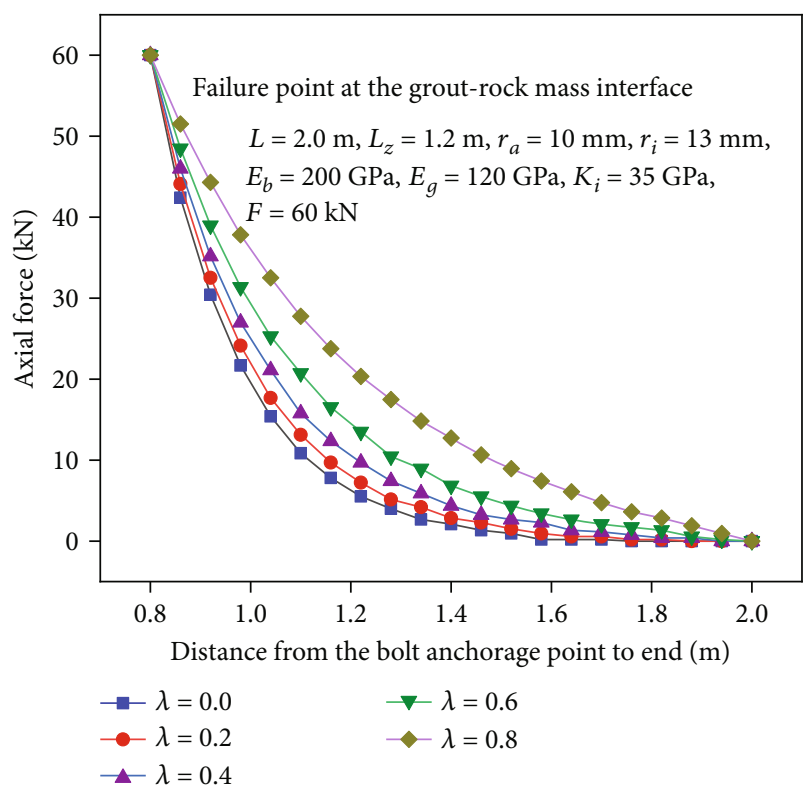

(b)

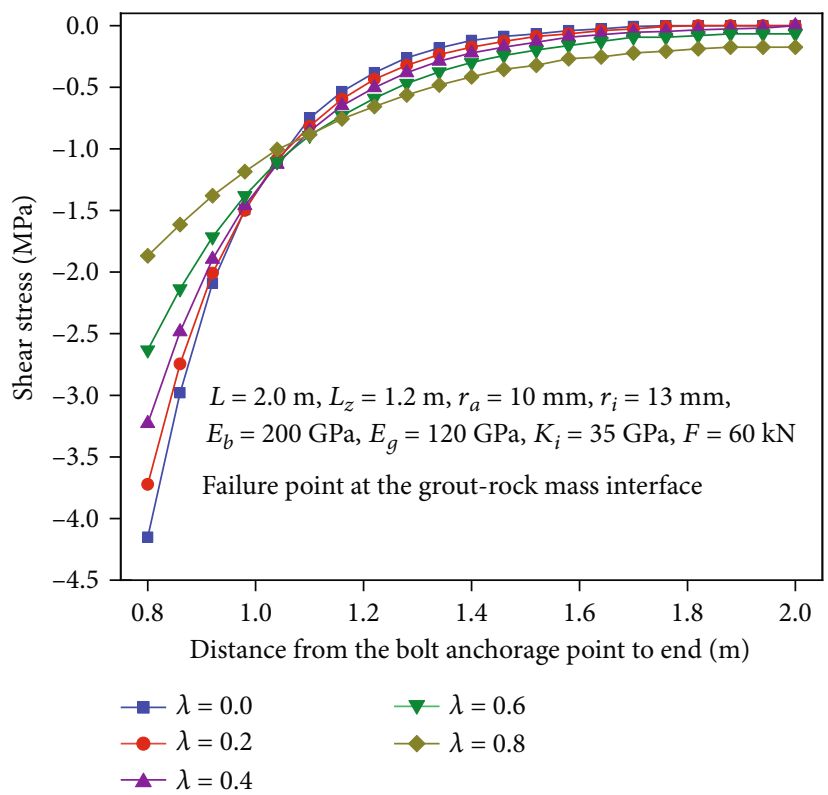

(d)

Figure 10: Axial force and shear stress evolution law of the anchorage body under different weakening coefficients. (a) Axial force (failure point at the grout-bolt interface); (b) axial force (failure point at the grout-rock mass interface); (c) shear stress (failure point at the groutbolt interface); (d) shear stress (failure point at the grout-rock mass interface).

\section{Establishment of a Numerical Simulation Model}

4.1. Establishment of a Numerical Simulation Model. The Fast Lagrangian Analysis of Continua in 3-Dimension (FLAC ${ }^{3 \mathrm{D}}$ ) software can effectively simulate the progressive failure and large deformation problem of the underground engineering compared with the ABAQUS or ANSYS software. Hence, FLAC $^{3 \mathrm{D}}$ has been widely applied to tunnel excavation and support design, slope, or foundation reinforcement engineering and mining engineering. From the previous analysis in this study, the B1002 haulage roadway of No.4 coal mine in Saier Group encountered a typical large deformation problem of soft rock roadway. Therefore, the FLAC ${ }^{3 \mathrm{D}}$ software was selected to research the failure mechanism of this roadway under different moisture contents. To remove the influence of the boundary effect on calculation results, the length, width, and height of the simulation model were set as $100 \mathrm{~m}, 25 \mathrm{~m}$, and $50 \mathrm{~m}$, respectively, as shown in Figure 11. The model size of the haulage roadway was 5.0 $\mathrm{m}$ (width) $\times 3.6 \mathrm{~m}$ (height); both the left-right boundary and the bottom boundary were subject to displacement 


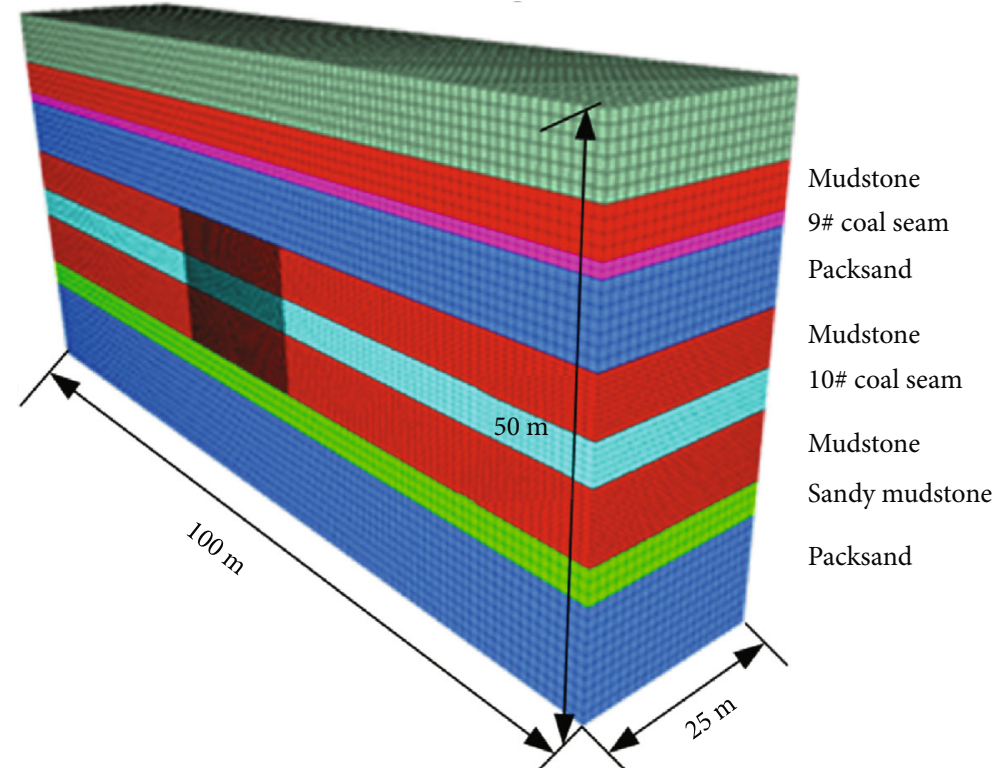

Figure 11: A numerical calculation model.

TABLE 3: Coal and rock mass mechanical parameters.

\begin{tabular}{|c|c|c|c|c|c|c|}
\hline Strata & $\begin{array}{l}\text { Bulk modulus } \\
(\mathrm{GPa})\end{array}$ & $\begin{array}{l}\text { Shear modulus } \\
(\mathrm{GPa})\end{array}$ & $\begin{array}{c}\text { Frictional angle } \\
\left({ }^{\circ}\right)\end{array}$ & $\begin{array}{c}\text { Cohesion } \\
(\mathrm{MPa})\end{array}$ & $\begin{array}{c}\text { Tensile strength } \\
(\mathrm{MPa})\end{array}$ & $\begin{array}{l}\text { Unit weight } \\
\left(\mathrm{kg} \cdot \mathrm{m}^{-3}\right)\end{array}$ \\
\hline Siltstone & 0.74 & 0.49 & 28 & 2.1 & 1.6 & 2550 \\
\hline Pack sand & 1.04 & 0.56 & 32 & 2.3 & 1.0 & 2540 \\
\hline Coal seam & 0.25 & 0.12 & 17 & 1.2 & 0.6 & 1370 \\
\hline Sandy mudstone & 0.56 & 0.35 & 24 & 1.5 & 0.4 & 2200 \\
\hline
\end{tabular}

TABle 4: Properties of the primary support bolt and cable in FLAC ${ }^{3 \mathrm{D}}$.

\begin{tabular}{|c|c|c|c|c|c|c|c|}
\hline Parameters & $\begin{array}{l}\text { Density } \\
\left(\mathrm{kg} \cdot \mathrm{m}^{-3}\right)\end{array}$ & $\begin{array}{c}\text { Cross-sectional area } \\
\left(\mathrm{cm}^{2}\right)\end{array}$ & $\begin{array}{c}\text { Elastic moduli } \\
\quad(\mathrm{GPa})\end{array}$ & $\begin{array}{c}\text { Tensile capability } \\
\qquad(\mathrm{kN})\end{array}$ & $\begin{array}{l}\text { Bond stiffness } \\
\qquad\left(\mathrm{N} / \mathrm{m}^{2}\right)\end{array}$ & $\begin{array}{l}\text { Bond cohesion } \\
(\mathrm{N} / \mathrm{m})\end{array}$ & $\begin{array}{l}\text { Preload } \\
(\mathrm{kN})\end{array}$ \\
\hline Bolt & 7500 & 3.80 & 200 & 120 & $2 \mathrm{e} 9$ & $4 \mathrm{e} 5$ & 30 \\
\hline Cable & 7500 & 2.81 & 200 & 300 & $2 \mathrm{e} 9$ & $4 \mathrm{e} 5$ & 60 \\
\hline
\end{tabular}

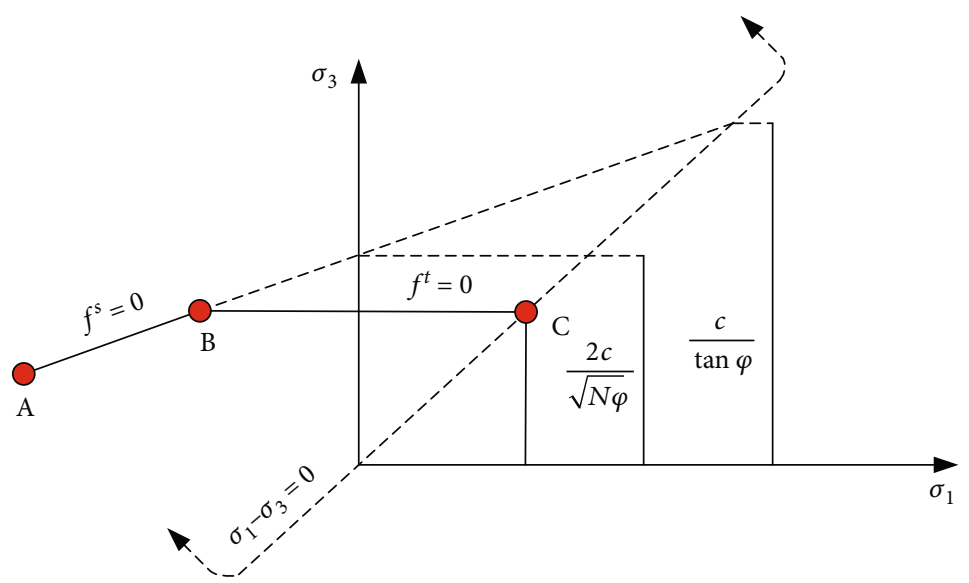

Figure 12: Mohr-Coulomb failure criterion in the plane $\left(\sigma_{1}-\sigma_{3}\right)$ for the FLAC ${ }^{3 \mathrm{D}}$. 


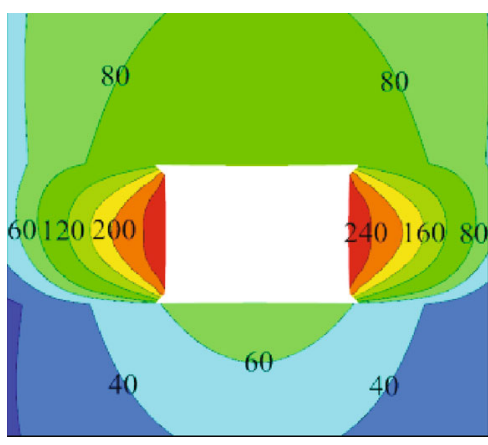

(a)

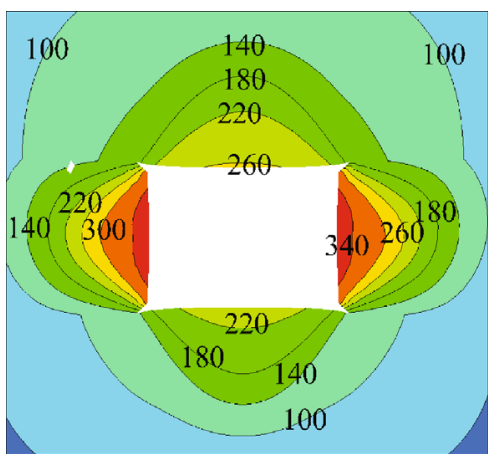

(c)

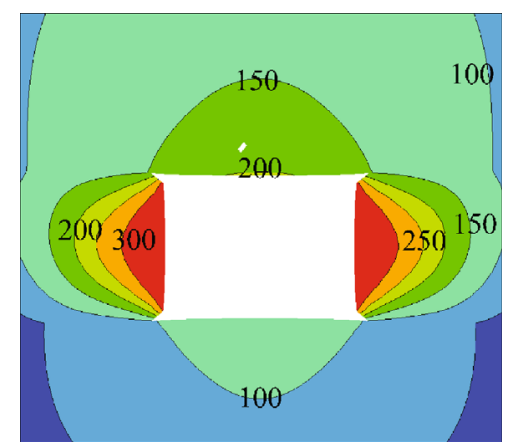

(b)

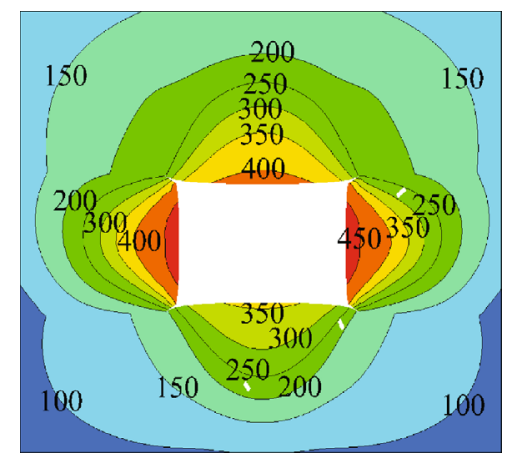

(d)

Figure 13: Total displacement maps of roadway without support under different moisture contents. (a) 2.42\%; (b) 3.33\%; (c) 4.54\%; (d) $5.56 \%$.

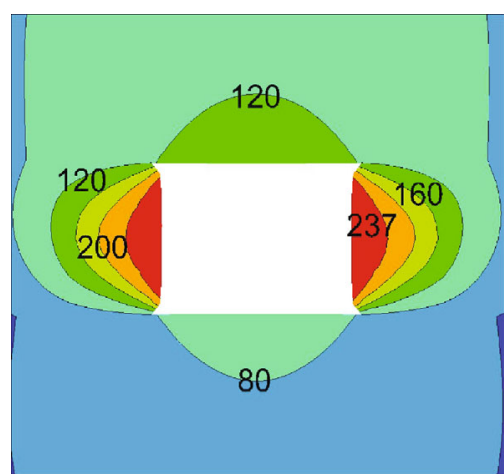

(a)

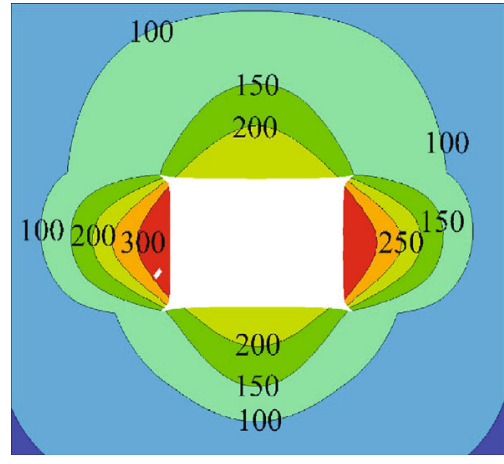

(c)

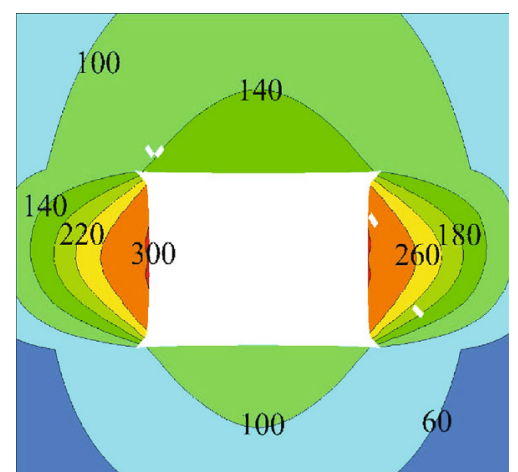

(b)

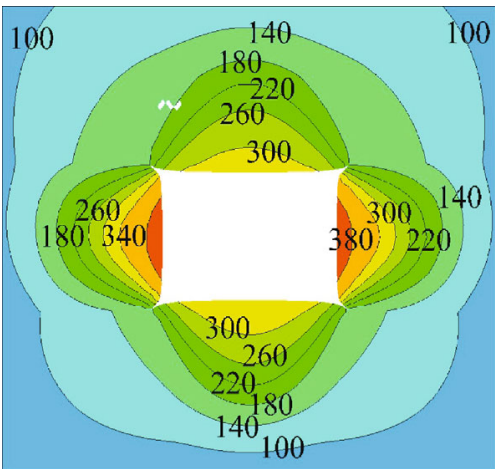

(d)

FIGURE 14: Total displacement maps of roadway with primary support under different moisture contents. (a) 2.42\%; (b) 3.33\%; (c) 4.54\%; (d) $5.56 \%$. 


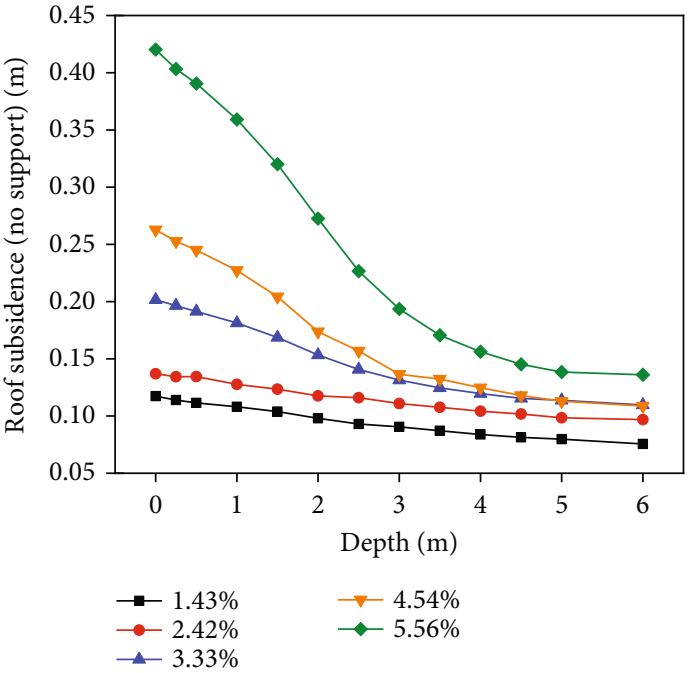

(a)

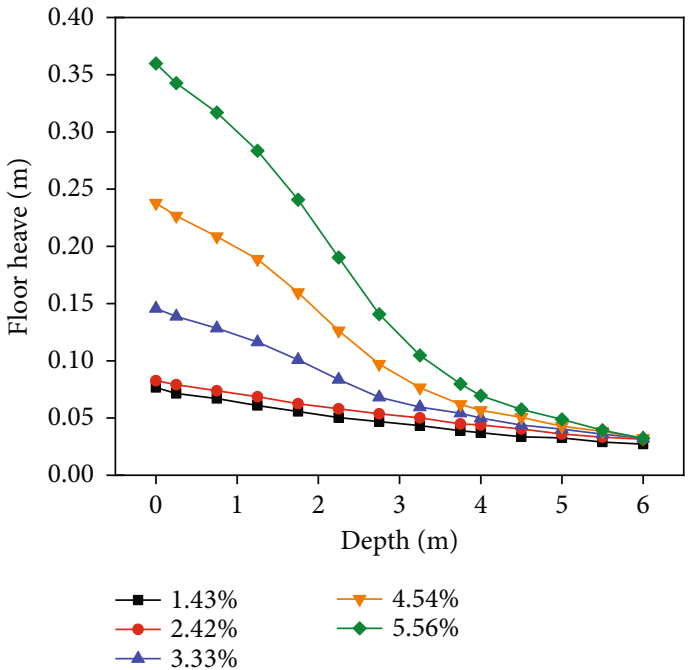

(b)

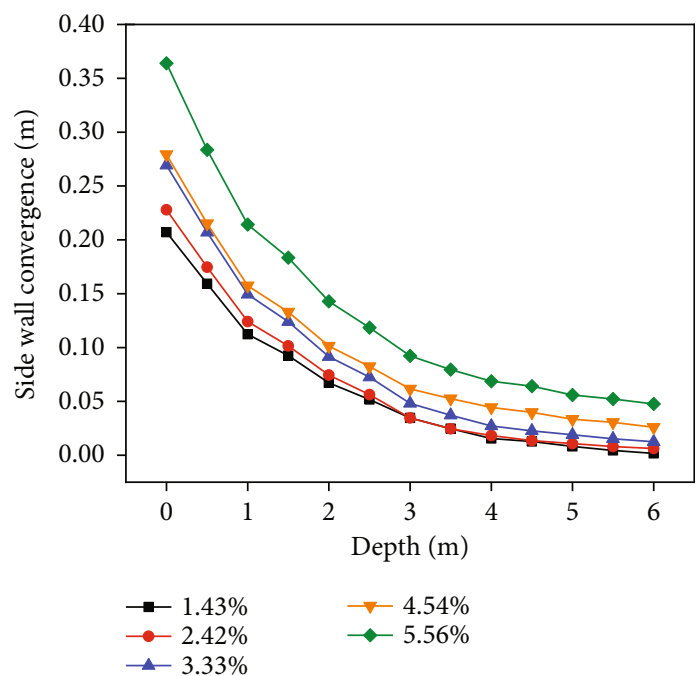

(c)

FIGURE 15: Displacement of roadway without support along the depth direction under different moisture contents. (a) Roof subsidence; (b) floor heave; (c) side wall convergence.

constraint, while the top boundary was subject to stress constraint with $10.5 \mathrm{MPa}$, which was measured by the field in situ stress test. To improve the calculation accuracy, the grid around the haulage roadway was encrypted. In this simulation, the in situ stress balance was first carried out, and then the total displacement and plastic zone of surrounding rock were extracted to research the failure process of haulage roadway considering the effect of different moisture contents after roadway excavation.

The mechanical parameters of the rock mass at different levels were easily obtained by laboratory tests. Table 2 presents the initial mechanical parameters of coal and rock mass taken from the geological report of the B1002 haulage roadway. To research the influence of mine water on the instability mechanism of the haulage roadway with the primary support and without any support, mudstone parameters were derived from Table 1 under different moisture contents. In addition, the Mohr-Coulomb criterion was used to simulate the failure of coal and rock masses. According to the engineering practice, the bolt-mesh-cable combined support was mainly adopted in the primary support of the haulage roadway. Geometric and mechanical parameters of bolt and cable are shown in Tables 3 and 4 .

4.2. Failure Criterion. Since the tensile strength of the rock mass was much lower than its compressive strength, the Mohr-Coulomb failure criterion was selected to realize the tension failure of the rock mass in this numerical simulation. The failure criterion might be represented in the plane $\left(\sigma_{1}-\sigma_{3}\right)$ as illustrated in Figure 12, and the failure envelope $f\left(\sigma_{1}, \sigma_{3}\right)=0$ is defined from point A to B by the MohrCoulomb failure function with

$$
f^{s}=\sigma_{1}-\sigma_{3} N_{\varphi}+2 c \sqrt{N_{\varphi}}
$$




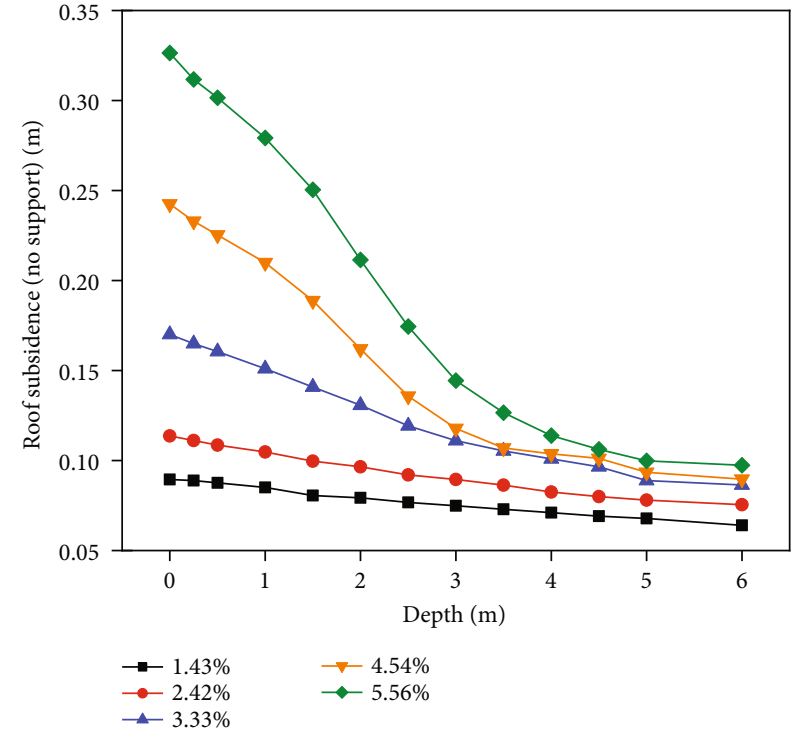

(a)

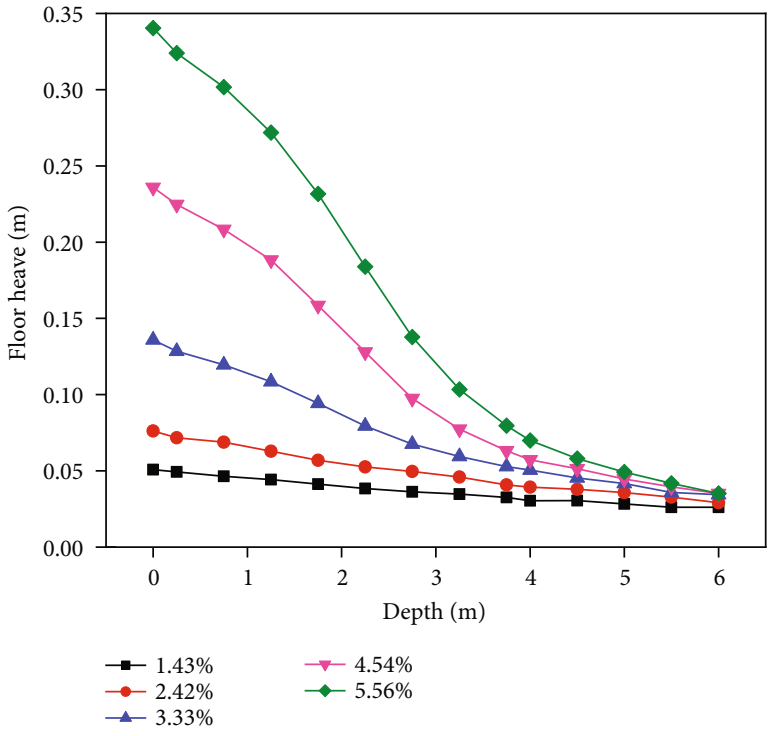

(b)

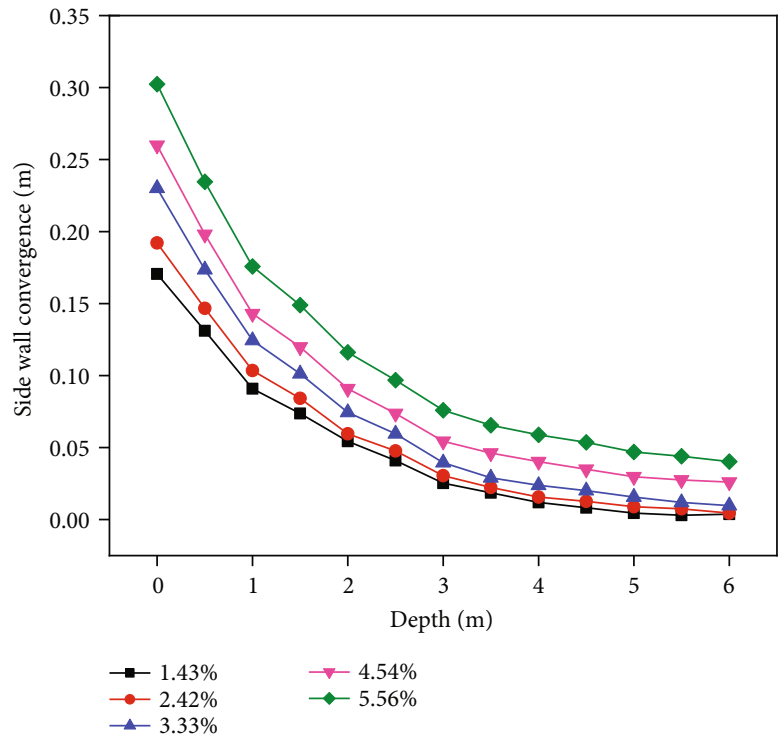

(c)

FIGURE 16: Displacement of roadway with primary support along the depth direction under different moisture contents. (a) Roof subsidence; (b) floor heave; (c) side wall convergence.

where $c$ is the cohesion; $\varphi$ is the internal friction angle, $N_{\varphi}$ $=(1+\sin \varphi) /(1-\sin \varphi)$. In addition, the tensile failure function from point $\mathrm{B}$ can be expressed as follows:

$$
f^{t}=\sigma_{t}-\sigma_{3}
$$

where $\sigma_{t}$ is the tensile strength.

\subsection{Failure Mechanism of Water-Dripping Mudstone Roadway}

4.3.1. Displacement Analyses. Figures 13 and 14 show the total displacement maps of surrounding rock with the primary support and without support under different moisture contents after the haulage roadway excavation. It is seen that the serious nonuniform deformation of roadway surrounding rock is caused by excavation and independent with the primary support or without support. The convergence deformation of side walls is obviously larger than that of the roof subsidence, while the floor heave is the smallest. For instance, when the moisture content is $4.54 \%$, the side wall convergence, roof subsidence, and floor heave of the roadway with the primary support are $669 \mathrm{~mm}, 264 \mathrm{~mm}$, and $237 \mathrm{~mm}$ without support, and $633 \mathrm{~mm}, 242 \mathrm{~mm}$, and $235 \mathrm{~mm}$, respectively.

In addition, with the increase of the moisture content, the deformation of surrounding rock of the roadway with the primary support and without support increases gradually, as shown in Figures 15-17. For instance, as the moisture content increases from $2.42 \%$ to $4.54 \%$, the side wall convergence, roof subsidence, and floor heave increase by $22.53 \%$, 


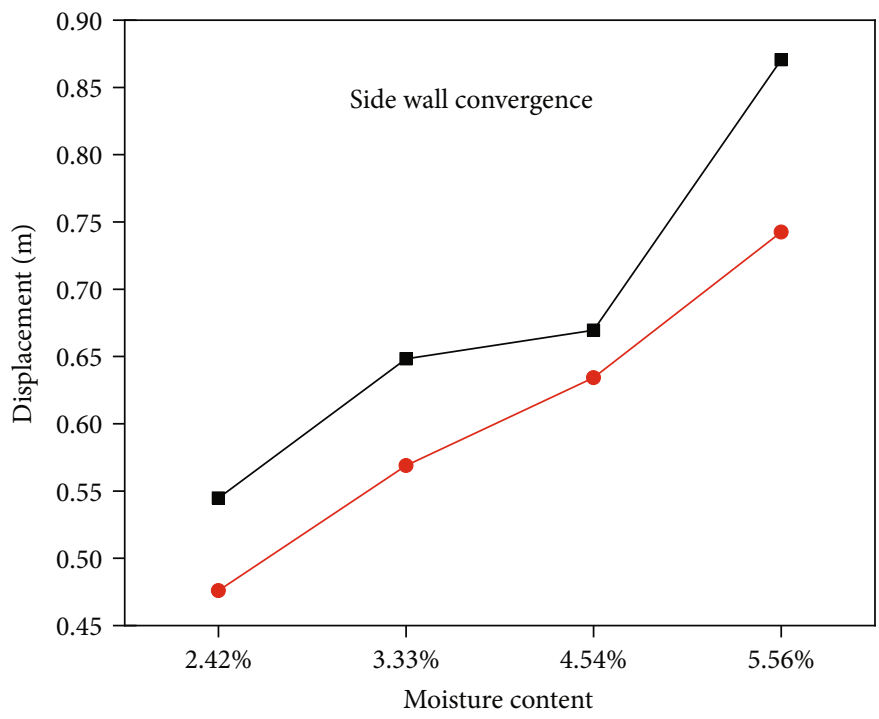

$\rightarrow-$ No support

$\rightarrow$ Support

(a)

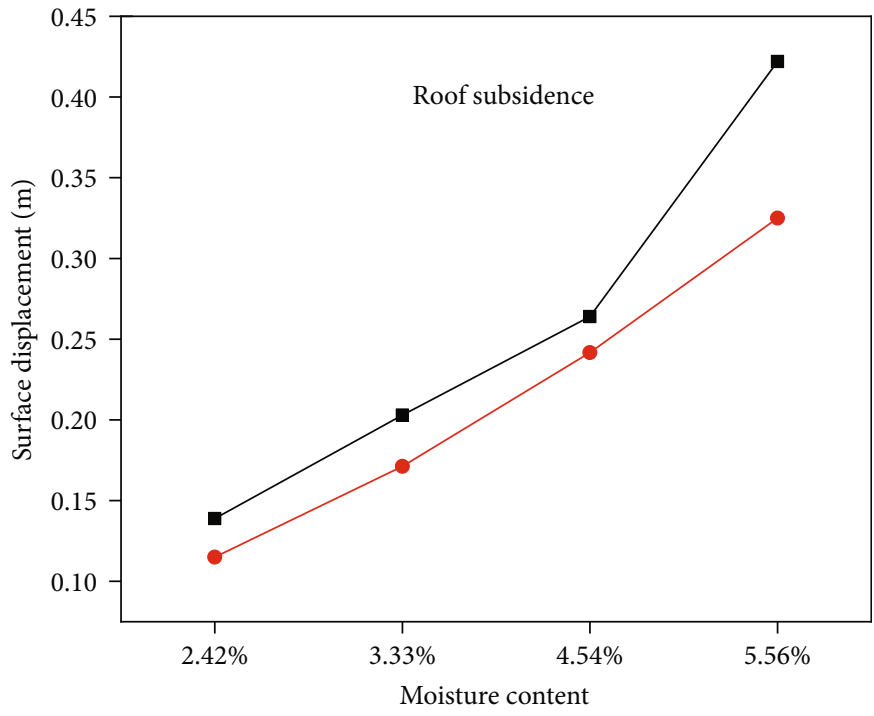

$\rightarrow-$ No support

- Support

(b)

Figure 17: Continued. 


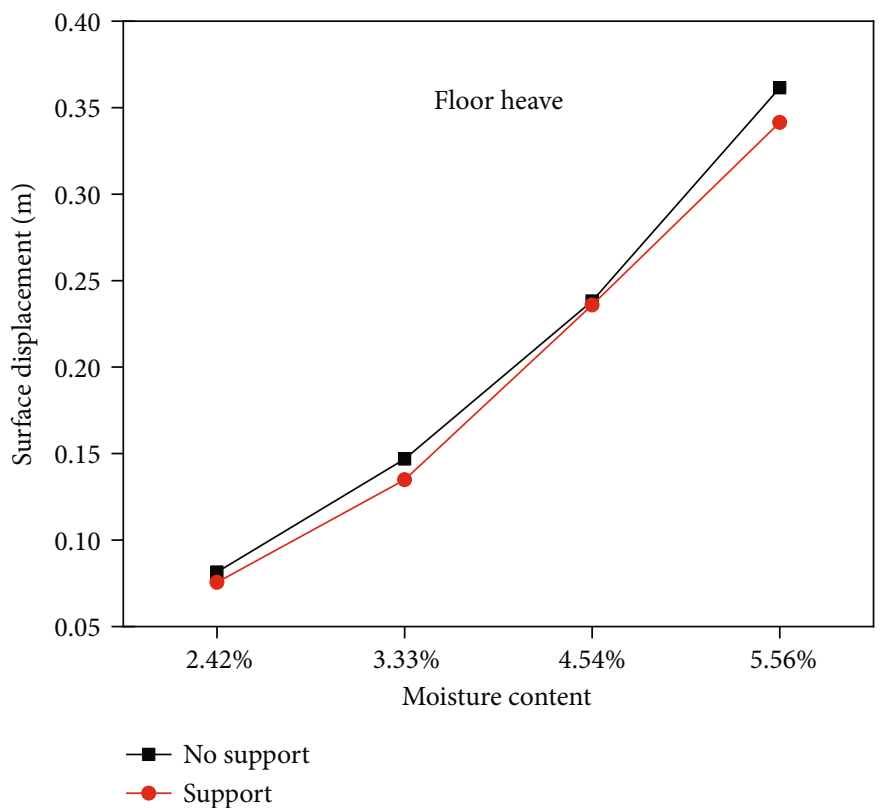

(c)

Figure 17: Surface displacement evolution law with the different moisture contents. (a) Side walls convergence; (b) roof subsidence; (c) floor heave.

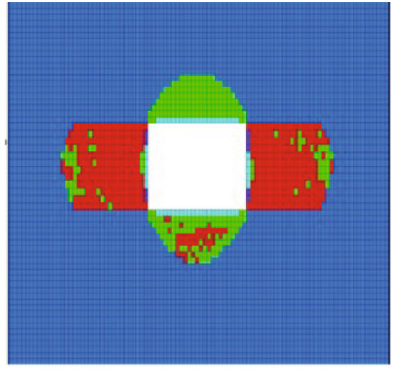

(a)

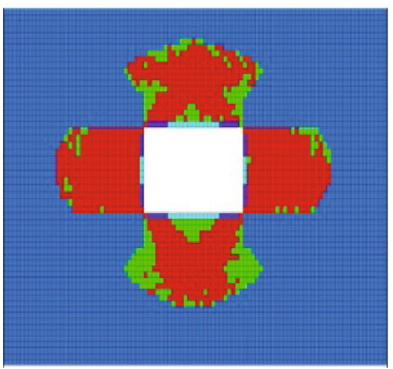

(c)

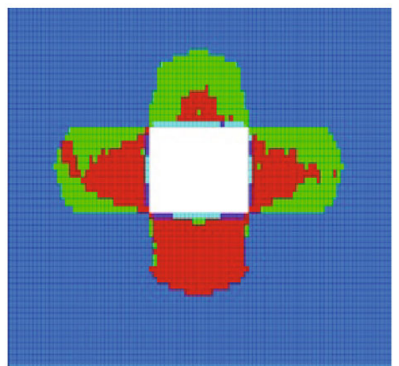

(b)

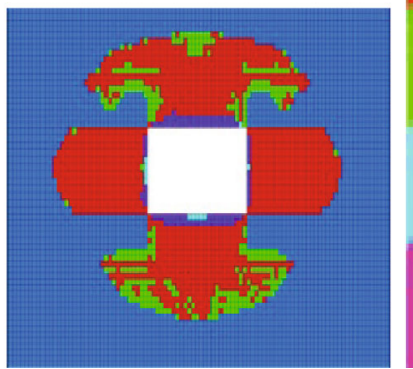

(d)
None

Shear-n shear-p

Tension- $\mathrm{p}$

Shear-n tension-n

Shear-p tension-p

Shear-p

Shear-p tension-p

Tension-n shear-p tension-p

FIGURE 18: Plastic zone distribution of roadway without support under different moisture contents. (a) 2.42\%; (b) 3.33\%; (c) 4.54\%; (d) $5.56 \%$ 。.

$91.30 \%$, and $185.54 \%$ for the roadway without the support and increase by $33.26 \%, 112.28 \%$, and $209.21 \%$ with the primary support, respectively. However, when the moisture content reaches $4.54 \%$, the deformation rate of side walls and roof begins to increase sharply for the roadway without the support, while the floor remains unchanged basically. In other words, the mine water has a great influence on the stability of surrounding rock, especially on the side walls and roof deformation.

Meanwhile, compared with the roadway without support, the maximum side wall convergence, roof subsidence, and floor heave of the roadway with the primary support only decrease by $13 \%-14.94 \%, 8.33 \%-22.57 \%$, and $0.84 \%-8.4 \%$, respectively, at the moisture content range of $2.42 \%-5.56 \%$. 


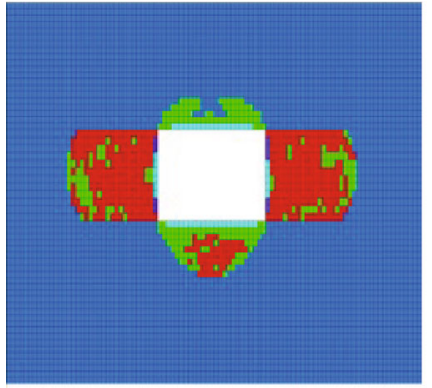

(a)

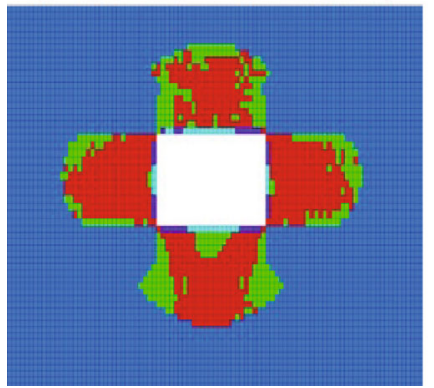

(c)

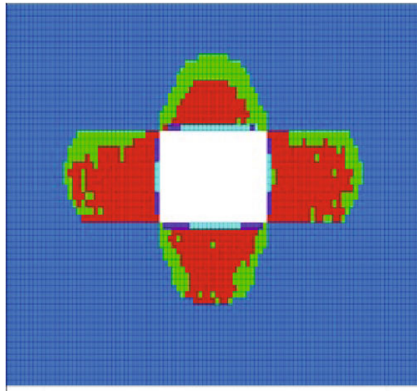

(b)

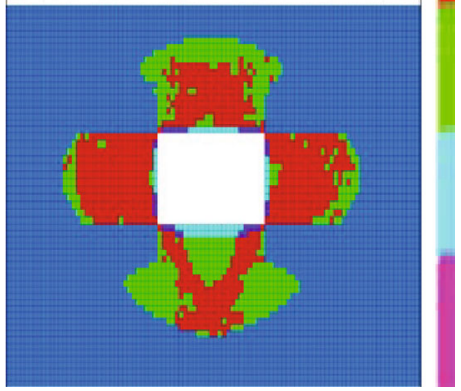

(d)
None

Shear-n shear-p

Tension-p

Shear-n tension-n

Shear-p tension-p

Shear-p

Shear-p tension-p

Tension-n shear-p tension-p

FIGURE 19: Plastic zone distribution of roadway with primary support under different moisture contents. (a) 2.42\%; (b) 3.33\%; (c) 4.54\%; (d) $5.56 \%$.

TABLe 5: Plastic zone distribution of roadway without support and with primary support.

\begin{tabular}{lcccccc}
\hline \multirow{2}{*}{ Moisture content (\%) } & \multicolumn{2}{c}{ Roof $(\mathrm{m})$} & \multicolumn{2}{c}{ Floor $(\mathrm{m})$} & \multicolumn{2}{c}{ Side walls (m) } \\
& No support & Primary support & No support & Primary support & No support & Primary support \\
\hline 2.42 & 2.4 & 1.5 & 2.7 & 2.7 & 4.4 & 4.2 \\
3.33 & 3.9 & 3.6 & 4.2 & 3.9 & 4.6 & 4.4 \\
4.54 & 4.5 & 4.2 & 4.8 & 4.8 & 4.4 & 4.8 \\
5.56 & 4.8 & 4.5 & 5.4 & 5.4 & 4.4 \\
\hline
\end{tabular}

It indicates that harmful deformation of surrounding rock is hardly controlled by the primary support, especially the side wall convergence under the high moisture content condition, as shown in Figure 14.

4.3.2. Crack and Plastic Region Analysis. Previous research has shown that engineering accidents in mine coal, such as roof caving and wall caving, are closely related to the propagation of the plastic zone. Therefore, the extension process of the plastic zone caused by excavation is urgent to be investigated. Figures 18 and 19 show plastic zone distribution maps of roadway without support and with primary support under different moisture contents. It is seen that tension-shear combined failure mainly occurred in the surface of the roadway, and shear failure occurred in deep surrounding rock, whether the roadway with the primary support or without the support. The plastic zone around the surrounding rock is in a shape of a cross.

In addition, with the increase of moisture contents, the plastic zone range for the roof and floor significantly increases, while that of side walls changes slightly. For instance, as the moisture content increases from $2.42 \%$ to $5.56 \%$, the ranges of the side walls only increase by $0.4 \mathrm{~m}$ for the roadway without support and $0.2 \mathrm{~m}$ with primary support, but the roof and floor increase by $2.4 \mathrm{~m}$ and $2.7 \mathrm{~m}$ without support or $3.0 \mathrm{~m}$ and $2.7 \mathrm{~m}$ without support, respectively, as shown in Table 5. In other words, the moisture content has the greatest influence on the plastic zone range of roof and floor, but has little influence on side walls.

As shown in Table 5, compared with the roadway without support, when the moisture content is $5.56 \%$, the ranges of plastic zone of the roadway with the primary support at $4.5 \mathrm{~m}$ roof and $4.4 \mathrm{~m}$ side walls only decrease by $0.3 \mathrm{~m}$ and $0.4 \mathrm{~m}$, respectively, while $5.4 \mathrm{~m}$ floor is unchanged. It indicates that the primary support cannot effectively control the development of the plastic zone, and there is still a large amount of shear failure around the roadway, especially on the floor.

4.3.3. Failure Mechanism Analysis. From the above analysis, the failure mechanism of the haulage roadway under the primary support can be summarized as follows:

High in situ stress, low-strength coal, and rock mass. The average burial depth of the haulage roadway is $320.66 \mathrm{~m}$ with relatively higher in situ stress $(10.5 \mathrm{MPa})$ combined with the influence of the tectonic stress. The natural compressive 


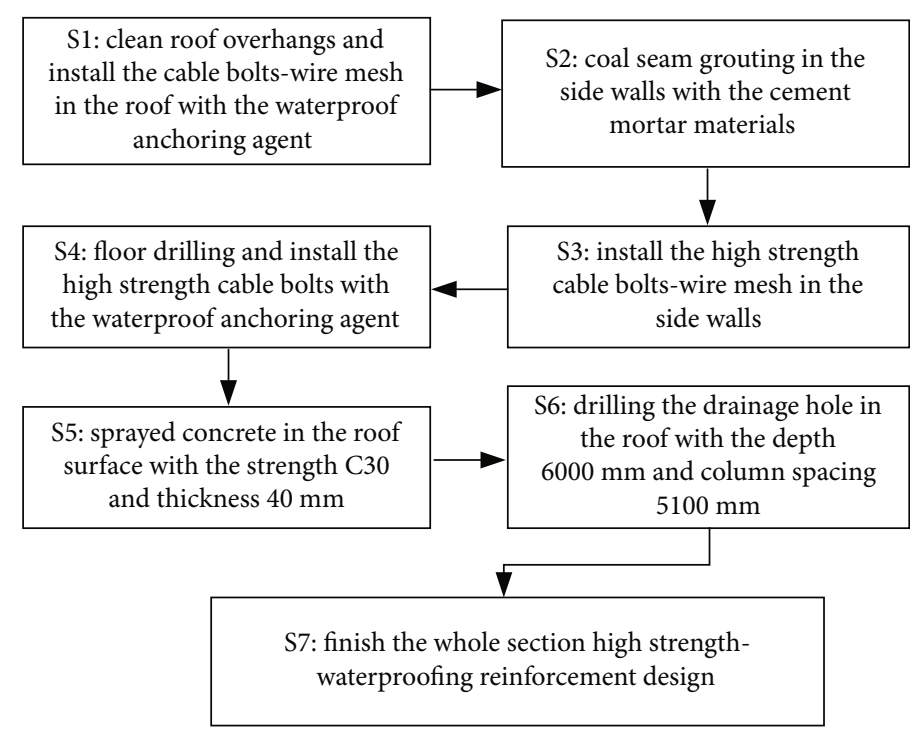

FIgURE 20: WSHSWRT support design.

strength of the coal and mudstone in the roof and floor is, respectively, 16.4 $\mathrm{MPa}$ and $3.24 \mathrm{MPa}$, belonging to the typical "three soft" coal seam roadway. The stress redistribution can occur after roadway excavation, and then, overburden stress exceeds the compressive strength of the rock masses, so that the shallow surrounding rock enters into the postfailure state first. The plastic zone is propagated from the shallow to the interior over time, resulting in the large broken rock mass zone finally.

Mudstone is weakened seriously, accelerating the deformation of surrounding rock. Pack sand layers near the roof and floor are rich in fissure water, which easily weakens the mudstone parameters. Then, the anchorage force and support strength of the bolt sharply drop with the attenuation of rock mass parameters. As a result, the harmful deformation of surrounding rock is accelerated to move towards the free face and reduce the instability process of haulage roadway.

Low-strength and incomplete support structure. Initial pretightening forces of the bolt and cable used in the primary support are only $30 \mathrm{kN}$ and $60 \mathrm{kN}$. However, they cannot provide enough compressive stress to prevent the tensile failure of shallow surrounding rock. The "bolt-mesh-cable" combined support is only used in the roof and side walls; then, a whole-section support structure around the haulage roadway cannot be formed to effectively resist the floor heave.

\section{The Support Approach of "Whole Section High Strength-Waterproofing Reinforcement Technology (WSHSWRT)"}

5.1. Control Principal. The support approach of WSHSWRT is mainly composed of the whole section high pretension bolt-cable, waterproof anchoring agent, shotcrete, and drainage hole in the roof as well as side wall grouting layer. Previous research has indicated that the confining pressure has an extremely important effect on the residual strength of rock mass [4]. The residual strength gradually increases with the increase of the confining pressure. Therefore, the whole section-high pretension bolt-cable support should be used to improve mechanical parameters and reduce the tensile failure of shallow surrounding rock including the floor heave. Furthermore, the cables of the roof and side walls should be anchored to packstone layers, so as to fully play the suspension action for the shallow surrounding rock. The strength of the coal is much lower than that of rock masses, which is the main reason for the large deformation of the two sides. The grouting technology improves the bond strength and the residual bearing capacity of cracked surrounding rock effectively and has been widely used in tunnel excavation engineering [23]. Therefore, the large deformation and plastic region of side convergence can be effectively controlled by the coal seam grouting. A series of drainage holes in the roof is arranged to reduce the influence of mine water on the mechanical properties of shallow surrounding rock. In addition, a hermetic high-strength integrated support structure is formed in the roof through the high strength shotcrete layer, so that the high resistance is provided to control the roof subsidence, and the surrounding rock is sealed to reduce the weathering of shallow mudstone. As we know, the weakening effect of mine water on the surrounding rock and anchoring agent is one of the main reasons for the bolt support failure. Therefore, the waterproof anchoring agent should be used to reduce the influence of mine water. Figure 20 shows the design process of the WSHSWRT support.

5.2. Support Parameters and Scheme. In the above analysis, WSHSWRT is proposed to solve the large deformation of the "three soft" mining roadway. The support technology is divided into the following aspects: the whole section boltcable high strength support structure (high strength boltcable-wire mesh), the coal seam grouting reinforcement, and supplementary support including shotcrete and drilling drainage holes in the roof. The excavation section of the 
TABLE 6: Bolt and cable properties of the combined support.

\begin{tabular}{|c|c|c|c|c|c|c|c|}
\hline Parameters & $\begin{array}{l}\text { Density } \\
\left(\mathrm{kg} \cdot \mathrm{m}^{-3}\right)\end{array}$ & $\begin{array}{c}\text { Cross-sectional area } \\
\left(\mathrm{cm}^{2}\right)\end{array}$ & $\begin{array}{l}\text { Elastic moduli } \\
(\mathrm{GPa})\end{array}$ & $\begin{array}{c}\text { Tensile capability } \\
(\mathrm{kN})\end{array}$ & $\begin{array}{l}\text { Bond stiffness } \\
\left(\mathrm{N} / \mathrm{m}^{2}\right)\end{array}$ & $\begin{array}{c}\text { Bond cohesion } \\
(\mathrm{N} / \mathrm{m})\end{array}$ & $\begin{array}{c}\text { Preload } \\
(\mathrm{kN})\end{array}$ \\
\hline Bolt & 7500 & 3.80 & 200 & 120 & $2 \times 10^{9}$ & $4 \times 10^{5}$ & 80 \\
\hline Cable & 7500 & 2.81 & 200 & 300 & $2 \times 10^{9}$ & $4 \times 10^{5}$ & 120 \\
\hline
\end{tabular}

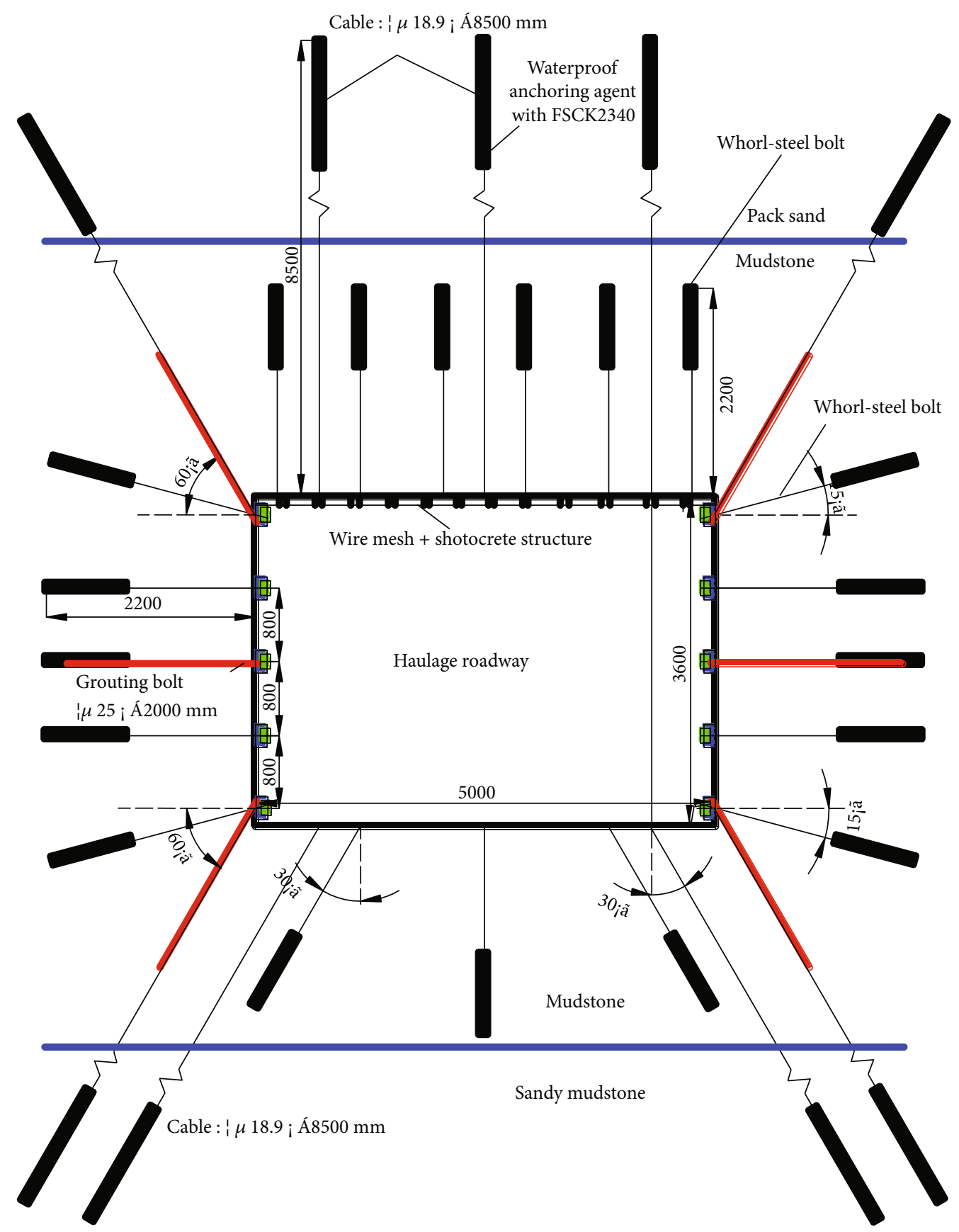

(a)

Figure 21: Continued. 


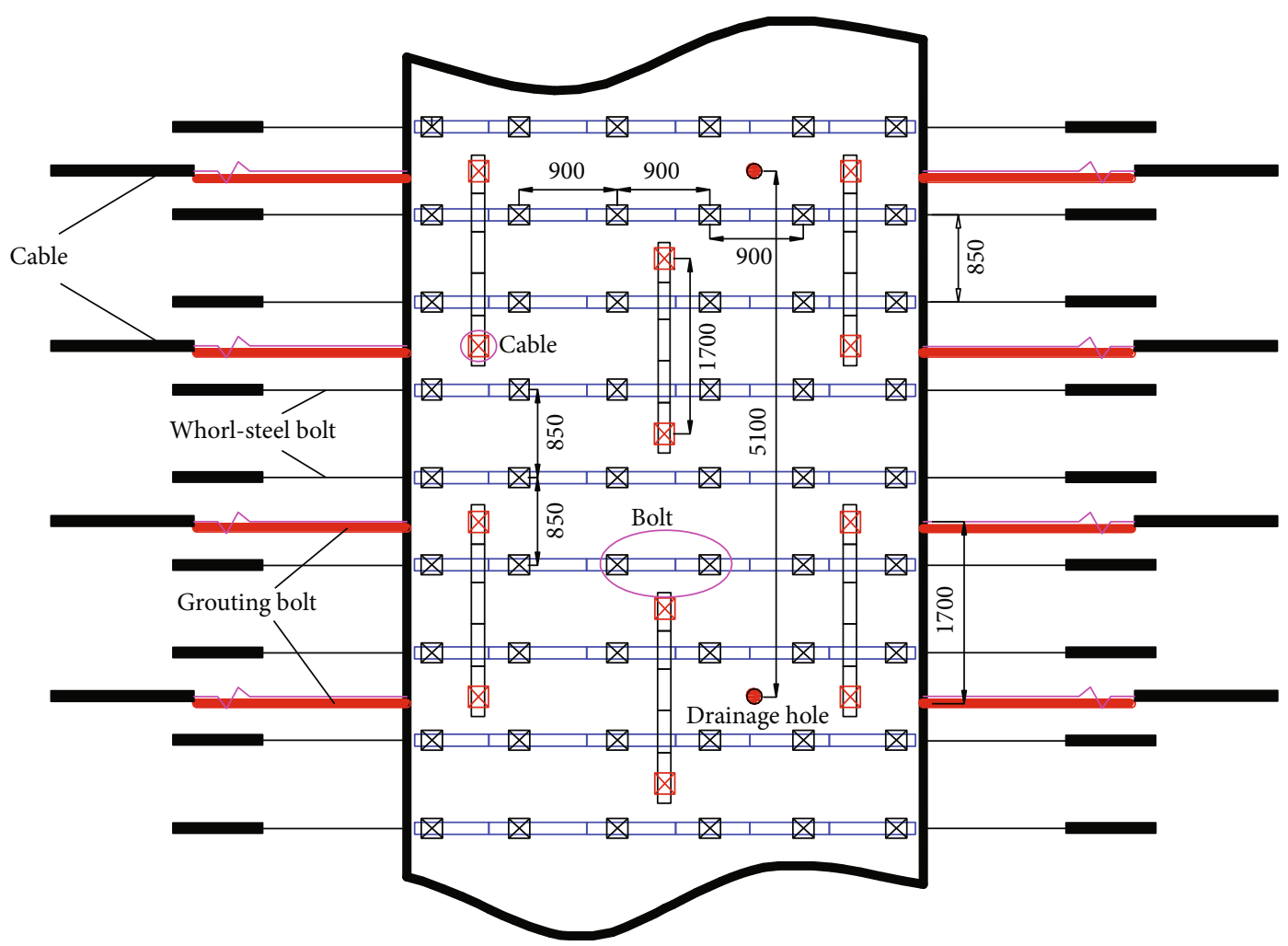

(b)

FIgURE 21: WSHSWRT of the haulage roadway. (a) Support section; (b) roof and side support.

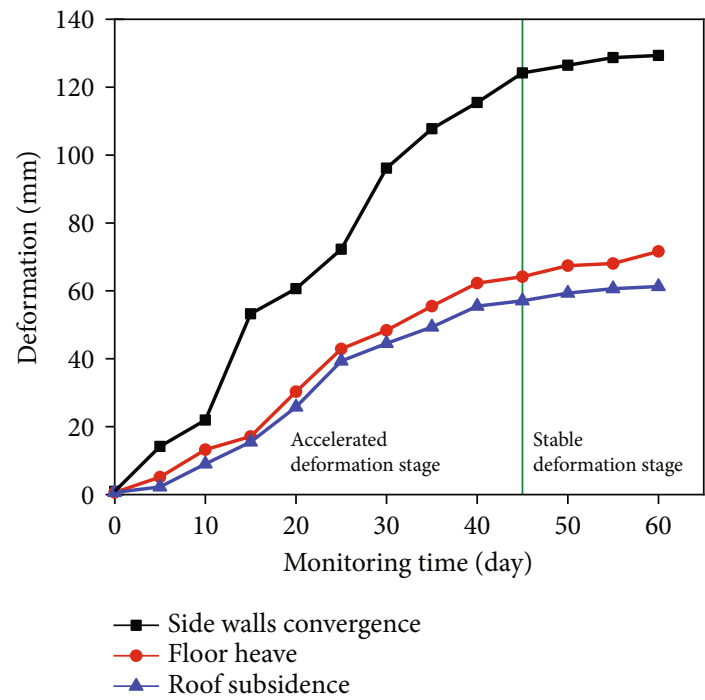

(a)

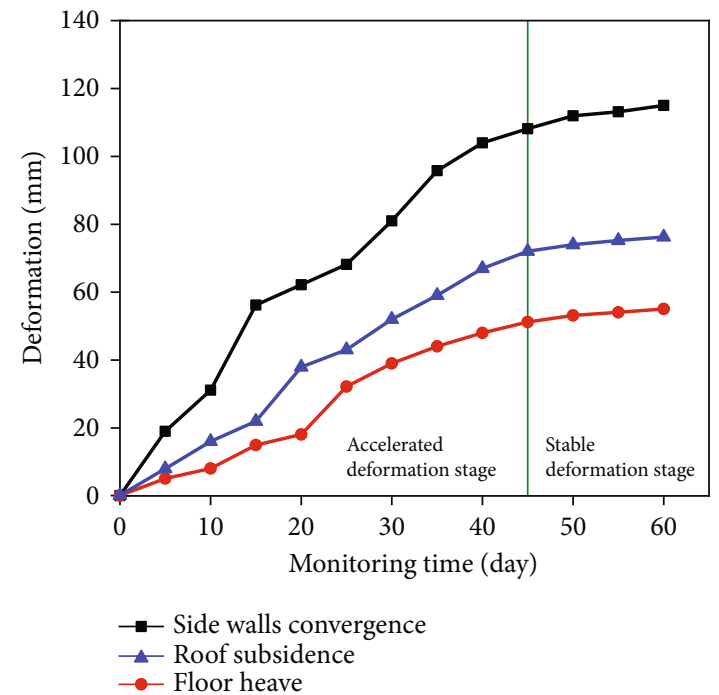

(b)

FIGURE 22: Surface convergence of haulage roadway at different monitoring points. (a) 2\# monitoring point; (b) 4\# monitoring point.

haulage roadway was rectangular with a width of $5.0 \mathrm{~m}$ and a height of $3.6 \mathrm{~m}$. The specific support parameter design is shown as follows.

Whole section bolt-cable high strength support. Sixteen $\Phi 22 \mathrm{~mm} \times 2200 \mathrm{~mm}$ high-strength bolts were installed in the roof and two sides with the row spacing and column spacing of $900 \mathrm{~mm} \times 850 \mathrm{~mm}$ and $800 \mathrm{~mm} \times 850 \mathrm{~mm}$. Three $\Phi 22 \mathrm{~mm} \times 2200 \mathrm{~mm}$ high-strength bolts were installed on the floor with the row spacing and column spacing of 1350 $\mathrm{mm} \times 850 \mathrm{~mm}$. The bolts installed in the top and bottom of the two sides were inclined at $15^{\circ}$. Nine $\Phi 18.9 \mathrm{~mm} \times 8500$ $\mathrm{mm}$ high-strength cables were installed in the roof, two sides, 
TABLE 7: Surface convergence of surrounding rock.

\begin{tabular}{lccc}
\hline $\begin{array}{l}\text { Time } \\
(\mathrm{d})\end{array}$ & $\begin{array}{c}\text { Roof subsidence } \\
(\mathrm{mm})\end{array}$ & $\begin{array}{c}\text { Floor heave } \\
(\mathrm{mm})\end{array}$ & $\begin{array}{c}\text { Side walls convergence } \\
(\mathrm{mm})\end{array}$ \\
\hline 0 & 0 & 0 & 0 \\
5 & 8 & 5 & 19 \\
10 & 16 & 8 & 31 \\
15 & 22 & 15 & 56 \\
20 & 38 & 18 & 62 \\
25 & 43 & 32 & 68 \\
30 & 52 & 39 & 81 \\
35 & 59 & 44 & 96 \\
40 & 67 & 48 & 104 \\
45 & 72 & 51 & 108 \\
50 & 74 & 53 & 112 \\
55 & 75 & 54 & 113 \\
60 & 76 & 55 & 115 \\
\hline
\end{tabular}

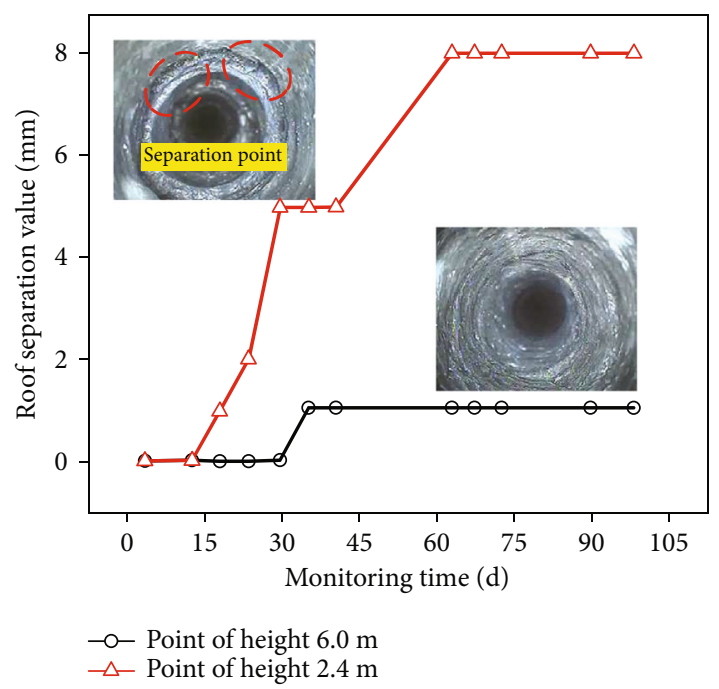

FIGURE 23: Separation monitoring of the roof with different heights.

and floor with the row spacing and column spacing of 1800 $\mathrm{mm} \times 1700 \mathrm{~mm}, 3200 \mathrm{~mm} \times 1700 \mathrm{~mm}$, and $3600 \mathrm{~mm} \times 1700$ $\mathrm{mm}$, respectively. The longitudinal connection along the roadway was adopted between two roof cables by the rebar beam, while vertical connection for the two sides cables. Cables installed in the top and bottom of the two sides were inclined at $60^{\circ}$. Bolts were designed to be installed with a steel strip $4700 \mathrm{~mm}$ long for the roof and $3400 \mathrm{~mm}$ long for the two sides as well as the wire mesh with a grid size of $50 \mathrm{~mm}$ $\times 50 \mathrm{~mm}$. The limit anchorage force of bolts and cables was no less than $120 \mathrm{kN}$ and $300 \mathrm{kN}$, respectively.

The waterproof anchoring agent with FSCK $2340 \times 4$ for cables and FSCK2340 $\times 2$ for bolts was applied to the roof to reduce the influence of mine water. The properties of bolts and cables are shown in Table 6.

Coal seam grouting reinforcement. Six $\Phi 25 \mathrm{~mm} \times 2000$ $\mathrm{mm}$ hollow grouting anchors were symmetrically installed on the two sides with the row spacing and column spacing of $1600 \mathrm{~mm} \times 1700 \mathrm{~mm}$. The grouting bolts of the top and bottom were inclined at $60^{\circ}$. The grouting pressure was maintained at $0.6 \mathrm{MPa}$. As cement grout has the characteristics of environmental protection, economy, and good durability compared with chemical grout, cement grout is selected as the grouting material. The grouting material was mainly composed of cement, sand, water reducer, and water in a ratio of $1: 1: 0.01: 0.32$.

The strength and average thickness of the shotcrete in the roof was C30 and $40 \mathrm{~mm}$, respectively. The drainage hole was drilled in the roof with a depth of $6000 \mathrm{~mm}$ and column spacing of $5100 \mathrm{~mm}$. The concrete combined support scheme is shown in Figure 21.

5.3. WSHSWRT Engineering Application. WSHSWRT was applied to the B1002 haulage roadway of No.4 coal mine. Five sections of the roadway were selected to monitor the surface convergence, fracture, and separation state of the roof to obtain the supporting effect of the proposed support scheme. The layout of the five monitoring points is shown in Figure 21(b).

5.3.1. Deformation Monitoring. The roof subsidence, floor heave, and side wall convergence at the $2 \#$ and $4 \#$ monitoring points are shown in Figure 22. Monitoring results indicated that the deformation can be divided into two stages. (1) Accelerated deformation stage: the surface deformation increased obviously with the monitoring time within 47 days after roadway excavation, owing to the release of surrounding rock deformation energy under the effect of supporting structures. However, the deformation ratio decreased gradually. (2) Stable deformation stage: the surface deformation tended to be stable after the excavation for 47 days. As shown in Table 7, the final roof subsidence, floor heave, and side wall convergence are only in the range of $71 \mathrm{~mm}-76 \mathrm{~mm}$ with the average deformation rate of $0.4 \mathrm{~mm} / \mathrm{d}, 55 \mathrm{~mm}-61 \mathrm{~mm}$ with the average deformation rate of $0.6 \mathrm{~mm} / \mathrm{d}$, and $115 \mathrm{~mm}$ $129 \mathrm{~mm}$ with the average deformation ration rate of $0.5 \mathrm{~mm} / \mathrm{d}$, respectively. From the above analysis, the deformation is within the allowable range, and the new supporting scheme can effectively control the large deformation of the haulage roadway.

5.3.2. Separation Monitoring. To evaluate the internal support effect of roof surrounding rock, the separation state of the roof at the $3 \#$ monitoring points with different heights of $2.4 \mathrm{~m}$ and $6.0 \mathrm{~m}$ was monitored by the separation instrument and JL-IDOI(A) electronic drilling peep instrument, as shown in Figure 23.

From Figure 23, it is seen that the maximum separation values of two monitoring points under WSHSWRT are only $1 \mathrm{~mm}$ with a height of $6.0 \mathrm{~m}$ and $8.0 \mathrm{~mm}$ with a height of $2.4 \mathrm{~m}$ after a 2-month roadway excavation, respectively. The above information indicated that the integrity of the roadway roof is good, and there will be no large-scale collapse and roof caving accidents. In other words, WSHSWRT can control the roof bed aspiration effectively and provide important maintenance for the long-term stability of the roof. 


\section{Conclusions}

(1) The surface deformation for the water-dripping roadway is noticeable and characterized by the large deformation and time-dependent properties during the roadway excavation, owing to the low strength support structure and the influence of mine water. The support structure failure, such as roof collapse, wire mesh tearing failure, and bolt corrosion failure, is not only related to unreasonable supporting structure and strength but also closely related to the weakening effect of mine water on the shallow mudstone

(2) With the increase of moisture contents, the compressive strength nonlinearly decreases, while tensile strength, Young's modulus, cohesion, and friction angle have an approximately linear decrease. Therefore, the influence of mine water should be considered in the instability mechanism and support scheme design

(3) With the increase of the weakening coefficient, the axial force of the anchorage body increases gradually from the anchorage initial point to the end of the bolt, while the maximum shear stress decreases gradually; when the weakening coefficient is small, the shear stress is mainly concentrated near the anchorage initial point, while the distribution of shear stress gradually transforms from the anchorage initial point to the whole length of the bolt with the increase of the weakening coefficient. The above analysis shows that the mine water not only affects the anchoring action of the bolt but also causes the redistribution of bolt axial force

(4) WSHSWRT is proposed to adjust the stress state and improve the support strength of surrounding rock. Field monitoring results show that the proposed support technology can effectively control the harmful deformation of the surrounding rock and maintain the long-term stability of the roadway. The case provides an important reference for studies on the failure mechanism and control technology in waterdripping soft rock roadway

\section{Data Availability}

The data used to support the findings of this study are included within the article.

\section{Conflicts of Interest}

The authors declare that they have no conflicts of interest.

\section{Acknowledgments}

This work was financially supported by the National Natural Science Foundation of China (51974295, U1803118, 51974296, and 51704277) and the Fundamental Research Funds for the Central Universities (2015XKZD06).

\section{References}

[1] M. C. He, "Rock mechanics and hazard control in deep mining engineering in China," in Proceedings ISRM International Symposium 2006 4th Asian Rock Mechanics Symposium, pp. 29-46, Singapore, SG, November 2006.

[2] C. Q. Ma, P. Wang, L. S. Jiang, and C. S. Wang, "Deformation and control countermeasure of surrounding rocks for waterdripping roadway below a contiguous seam goaf," Processes, vol. 6, no. 7, p. 77, 2018.

[3] P. Kang, L. Hong, Y. Fazhi, Z. Quanle, S. Xiao, and L. Zhaopeng, "Effects of temperature on mechanical properties of granite under different fracture modes," Engineering Fracture Mechanics, vol. 226, p. 106838, 2020.

[4] S. Q. Yang, M. Chen, H. W. Jing, K. F. Chen, and B. Meng, "A case study on large deformation failure mechanism of deep soft rock roadway in Xin'an coal mine, China," Engineering Geology, vol. 217, pp. 89-101, 2017.

[5] D. Ma, J. J. Wang, X. Cai et al., "Effects of height/diameter ratio on failure and damage properties of granite under coupled bending and splitting deformation," Engineering Fracture Mechanics, vol. 220, p. 106640, 2019.

[6] Y. Xue, F. Gao, X. G. Liu, and X. Liang, "Permeability and pressure distribution characteristics of the roadway surrounding rock in the damaged zone of an excavation," International Journal of Mining Science and Technology, vol. 27, no. 2, pp. 211-219, 2017.

[7] Q. Wang, R. Pan, B. Jiang et al., "Study on failure mechanism of roadway with soft rock in deep coal mine and confined concrete support system," Engineering Failure Analysis, vol. 81, pp. 155-177, 2017.

[8] X. F. Li, S. B. Wang, R. Malekian, S. Q. Hao, and Z. X. Li, "Numerical simulation of rock breakage modes under confining pressures in deep mining: an experimental investigation," IEEE Access, vol. 4, pp. 5710-5720, 2016.

[9] C. R. Zhang, X. C. Yang, G. F. Ren, B. Ke, and Z. L. Song, "Instability of gypsum mining goaf under the influence of typical faults," IEEE Access, vol. 7, pp. 88635-88642, 2019.

[10] L. Zhu, Q. L. Yao, Z. Xia, W. N. Wang, and X. H. Li, "Study on the movement characteristics of the overlying stratum and surrounding rock control in ultraclose coal seams: a case study," Energy Science \& Engineering, vol. 8, no. 4, pp. 1231-1246, 2020.

[11] C. Mark, W. Gale, D. Oyler, and J. Chen, "Case history of the response of a longwall entry subjected to concentrated horizontal stress," International Journal of Rock Mechanics and Mining Sciences, vol. 44, no. 2, pp. 210-221, 2007.

[12] B. T. Shen, "Coal mine roadway stability in soft rock: a case study," Rock Mechanics and Rock Engineering, vol. 47, no. 6, pp. 2225-2238, 2014.

[13] S. B. Tang and C. A. Tang, "Numerical studies on tunnel floor heave in swelling ground under humid conditions," International Journal of Rock Mechanics and Mining Sciences, vol. 55, no. 10, pp. 139-150, 2012.

[14] C. González-Nicieza, A. E. Álvarez-Vigil, A. Menéndez-Díaz, and C. González-Palacio, "Influence of the depth and shape of a tunnel in the application of the convergenceconfinement method," Tunnelling and Underground Space Technology, vol. 23, no. 1, pp. 25-37, 2008.

[15] R. Pan, Q. Wang, B. Jiang et al., "Failure of bolt support and experimental study on the parameters of bolt-grouting for 
supporting the roadways in deep coal seam," Engineering Failure Analysis, vol. 80, pp. 218-233, 2017.

[16] D. Ma, H. Y. Duan, X. B. Li, Z. H. Li, Z. L. Zhou, and T. B. Li, "Effects of seepage-induced erosion on nonlinear hydraulic properties of broken red sandstones," Tunnelling and Underground Space Technology, vol. 91, p. 102993, 2019.

[17] S. M. Chen, A. Wu, Y. Wang, X. Chen, R. Yan, and H. Ma, "Study on repair control technology of soft surrounding rock roadway and its application," Engineering Failure Analysis, vol. 92, pp. 443-455, 2018.

[18] K. Peng, Y. Q. Wang, Q. L. Zou, Z. P. Liu, and J. H. Mou, "Effect of crack angles on energy characteristics of sandstones under a complex stress path," Engineering Fracture Mechanics, vol. 218, p. 106577, 2019.

[19] W. J. Yu, B. Pan, F. Zhang, S. F. Yao, and F. F. Liu, "Deformation characteristics and determination of optimum supporting time of alteration rock mass in deep mine," KSCE Journal of Civil Engineering, vol. 23, no. 11, pp. 4921-4932, 2019.

[20] L. Sun, H. Wu, B. Yang, and Q. Li, "Support failure of a highstress soft-rock roadway in deep coal mine and the equalized yielding support technology: a case study," International Journal of Coal Science \& Technology, vol. 2, no. 4, pp. 279-286, 2015.

[21] P. Lin, H. Y. Liu, and W. Y. Zhou, "Experimental study on failure behaviour of deep tunnels under high in-situ stresses," Tunnelling and Underground Space Technology, vol. 46, pp. 28-45, 2015.

[22] L. Jiang, P. Wang, P. Zheng, H. Luan, and C. Zhang, "Influence of different advancing directions on mining effect caused by a fault," Advances in Civil Engineering, vol. 2019, Article ID 7306850, 10 pages, 2019.

[23] W. Fangtian, Z. Cun, W. Shuaifeng, Z. Xiaogang, and G. Shenghua, "Whole section anchor-grouting reinforcement technology and its application in underground roadways with loose and fractured surrounding rock," Tunnelling and Underground Space Technology, vol. 51, pp. 133-143, 2016.

[24] H. Yu, L. G. Kong, Z. Y. Niu, S. T. Zhu, and D. Y. Jing, "Numerical simulation of bolt-mesh-anchor support technology at soft rock roadway," Advanced Materials Research, vol. 868, pp. 251-254, 2013.

[25] X. Chang, Y. Y. Wei, and Y. C. Yun, "Analysis of steelreinforced concrete-filled-steel tubular (SRCFST) columns under cyclic loading," Construction and Building Materials, vol. 28, no. 1, pp. 88-95, 2012.

[26] Y. Wu, Y. Hao, J. Tao, Y. Teng, and X. Dong, "Non-destructive testing on anchorage quality of hollow grouted rock bolt for application in tunneling, lessons learned from their uses in coal mines," Tunnelling and Underground Space Technology, vol. 93, article 103094, 2019.

[27] H. B. Ge and T. Usami, "Strength analysis of concrete-filled thin-walled steel box columns," Journal of Constructional Steel Research, vol. 30, no. 3, pp. 259-281, 1994.

[28] Y. Y. Jiao, L. Song, X. Z. Wang, and A. Coffi Adoko, "Improvement of the U-shaped steel sets for supporting the roadways in loose thick coal seam," International Journal of Rock Mechanics and Mining Sciences, vol. 60, pp. 19-25, 2013.

[29] D. Ma, J. J. Wang, and Z. H. Li, "Effect of particle erosion on mining-induced water inrush hazard of karst collapse pillar," Environmental Science and Pollution Research, vol. 26, no. 19, pp. 19719-19728, 2019.
[30] Y. Sun, G. Li, J. Zhang, and D. Qian, "Experimental and numerical investigation on a novel support system for controlling roadway deformation in underground coal mines," Energy Science \& Engineering, vol. 8, no. 2, pp. 490-500, 2020.

[31] Z. Yin, W. Chen, H. Hao et al., "Dynamic compressive test of gas-containing coal using a modified Split Hopkinson pressure bar system," Rock Mechanics and Rock Engineering, vol. 53, no. 2, pp. 815-829, 2020.

[32] P. Wang, L. S. Jiang, P. Q. Zheng, G. P. Qin, and C. Zhang, "Inducing mode analysis of rock burst in fault-affected zone with a hard-thick stratum occurrence," Environmental Earth Sciences, vol. 78, no. 15, 2019.

[33] F. Zhang, L. Liu, J. Cao, X. Yan, and F. Zhang, "Mechanism and application of concrete-filled steel tubular support in deep and high stress roadway," Construction and Building Materials, vol. 186, pp. 233-246, 2018.

[34] C. Li, J. H. Xu, C. S. Fu, R. Wu, and Q. Q. Ma, "Mechanism and practice of rock control in deep large span cut holes," Mining Science and Technology (China), vol. 21, no. 6, pp. 891-896, 2011.

[35] H. L. Liu, W. C. Zhu, Y. J. Yu, T. Xu, R. F. Li, and X. G. Liu, "Effect of water imbibition on uniaxial compression strength of sandstone," International Journal of Rock Mechanics and Mining Sciences, vol. 127, article 104200, 2020. 